\title{
Biosafe Management of Botrytis Grey Mold of Strawberry Fruit by Novel Bioagents
}

\author{
Elhagag A. Hassan ${ }^{1, *(D)}$, Yasser S. Mostafa ${ }^{2}$, Saad Alamri ${ }^{2}$, Mohamed Hashem ${ }^{2, *(D)}$ and Nivien A. Nafady ${ }^{1}$ \\ 1 Botany Department, Faculty of Science, Assiut University, Assiut 71516, Egypt; niviennafady@aun.edu.eg \\ 2 Biology Department, Faculty of Science, King Khalid University, P.O. Box 10255, Abha 61321, Saudi Arabia; \\ ysolhasa1969@hotnail.com (Y.S.M.); saralomari@kku.edu.sa (S.A.) \\ * Correspondence: elhagaghassan@aun.edu.eg (E.A.H.); mhashem@kku.edu.sa (M.H.); \\ Tel.: +966-17-241-7625 (M.H.); Fax: +966-17-241-8202 (M.H.)
}

check for updates

Citation: Hassan, E.A.; Mostafa, Y.S.; Alamri, S.; Hashem, M.; Nafady, N.A. Biosafe Management of Botrytis Grey Mold of Strawberry Fruit by Novel Bioagents. Plants 2021, 10, 2737. https://doi.org/10.3390/ plants10122737

Academic Editor: Adriano Sofo

Received: 22 October 2021

Accepted: 9 December 2021

Published: 12 December 2021

Publisher's Note: MDPI stays neutral with regard to jurisdictional claims in published maps and institutional affiliations.

Copyright: (c) 2021 by the authors. Licensee MDPI, Basel, Switzerland. This article is an open access article distributed under the terms and conditions of the Creative Commons Attribution (CC BY) license (https:/ / creativecommons.org/licenses/by/ $4.0 /)$.

\begin{abstract}
Recently, there have been urgent economic and scientific demands to decrease the use of chemical fungicides during the treatment of phytopathogens, due to their human health and environmental impacts. This study explored the biocontrol efficacy of novel and eco-friendly preen (uropygial) oil and endophytic Bacillus safensis in managing postharvest Botrytis grey mold in strawberry fruit. The preen oil $(25 \mu \mathrm{L} / \mathrm{mL})$ showed high antifungal activity against $B$. cinerea $\operatorname{Str} 5$ in terms of the reduction in the fungal radial growth $(41.3 \%)$ and the fungal colony-forming units (28.6\%) compared to the control. A new strain of Bacillus safensis B3 had a good potential to produce chitinase enzymes $(3.69 \pm 0.31 \mathrm{U} / \mathrm{mL})$, hydrolytic lipase $(10.65 \pm 0.51 \mathrm{U} / \mathrm{mL})$, and protease enzymes $(13.28 \pm 0.65 \mathrm{U} / \mathrm{mL})$, which are responsible for the hydrolysis of the B. cinerea Str5 cell wall and, consequently, restrict fungal growth. The in vivo experiment on strawberry fruit showed that preen (uropygial) oil reduced the disease severity by $87.25 \%$, while the endophytic bacteria B. safensis B3 reduced it by $86.52 \%$. This study reports the efficiency of individually applied bioagents in the control of phytopathogenic fungi for the first time and, consequently, encourages their application as a new and innovative strategy for prospective agricultural technology and food safety.
\end{abstract}

Keywords: Botrytis cinerea; Bacillus safensis; preen (uropygail) oil; strawberry; postharvest disease; innovative strategy

\section{Introduction}

Strawberry (Fragaria ananassa Duch.; Family: Rosaceae) is an important and high-value fruit due to its unique flavor and its nutritional and health benefits [1], and is one of the most widely consumed berries in the world. However, strawberries may be exposed to mechanical injury and decay during harvesting and storage, increasing their susceptibility to various phytopathogens, including viruses, bacteria, and fungi [2,3]. B. cinerea is one of the most common fungal pathogens for strawberry infections, causing a destructive grey mold disease [4]. B. cinerea infects various strawberry organs in the field, including fruits during storage, resulting in poor yield quality [1,5]. Consequently, the infection of strawberries by $B$. cinerea causes serious economic crop loss in preharvest stages during growing seasons, harvesting time, and handling processes, as well as in postharvest stages during transportation and storage conditions [6]. It was reported that the strawberry yield loss may exceed 50\% in favorable environmental conditions due to the development of Botrytis grey mold [7]. To date, the most efficient tactics to control the postharvest pathogen B. cinerea depend mainly on the application of fungicides [8], although there are urgent economic and scientific demands to decrease the use of chemical fungicides due to their human health and environmental impacts $[9,10]$, as well as the development of new fungicide-resistant fungal strains [11]. As of recently, in some European countries, fungicides are fully forbidden during the postharvest stage [9]. Consequently, the discovery of new, innovative, and environmentally friendly strategies has become a vital trend to 
control fungal pathogens $[5,12,13]$. Applying different essential oils and medicinal plant extracts might be a sustainable environmental and economical solution for controlling phytopathogens due to their having little or no toxicity to humans and the environment [14]. In this context, the search for innovative, safer, and available alternatives that are derived naturally must be developed in order to decrease the postharvest fruit losses. Preen (uropygial) oil is a waxy substance extracted from birds' feathers, and shows high efficiency in inhibiting the growth of microorganisms $[15,16]$. However, to date, there are no available studies concerning the application of preen oil against phytopathogens. We assume that preen (uropygial) oil may be used as a biocontrol agent to suppress phytopathogens.

In addition, the application of microbial antagonists as biocontrol agents in managing postharvest fruit diseases is considered to be an environmentally safe and promising tactic [17]. Many antagonistic microorganisms-including bacteria, fungi, and yeastsshow high efficiency against various postharvest fruit diseases [18-20]. For B. cinerea grey mold disease management, the current study aimed to investigate the efficiency of both preen (uropygial) oil-extracted from chicken feathers-and the endophytic bacteria Bacillus safensis, as safe and effective alternative biocontrol agents against $B$. cinerea, as well as to investigate the impact of combined antagonistic bacteria and preen oil for the biocontrol of $B$. cinerea grey mold disease.

\section{Results}

\subsection{Identification and Pathogenicity of the Fungal Pathogen}

Botrytis cinerea Str5 was isolated from strawberry fruit showing grey mold symptoms. Based on the cultural and microscopic characteristics, the recovered fungus was identified as B. cinerea Str5 (Figure 1). The pathogenicity test of B. cinerea Str5 for strawberry fruit proved the severity of the isolated fungus, as well as its involvement in the development of the grey mold symptoms on the fruit. The fungus recorded a high level of colonization of the infected fruit within 5 days. The produced symptoms of the infected fruit showed a visible white-to-greyish cottony mass of the fungal mycelium, along with abundant fungal sporulation of conidiophores and fungal conidia on the rotted strawberry tissues (Figure 2). The fungal infection was also confirmed with scanning electron micrographs showing the colonization of conidiophores and fungal mycelia on the surface of the strawberry fruit (Figure 2), whereas scanning electron micrographs of uninfected strawberry fruits showed fine and smooth fruit morphology without any growing mycelia.

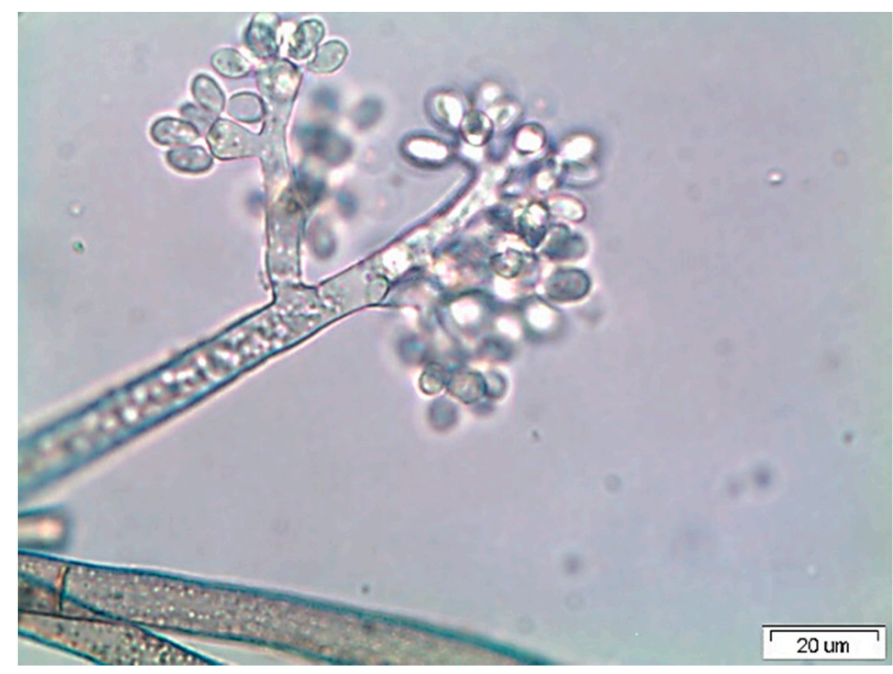

Figure 1. Botrytis cinerea Str5-the causal agent of strawberry grey mold disease. 

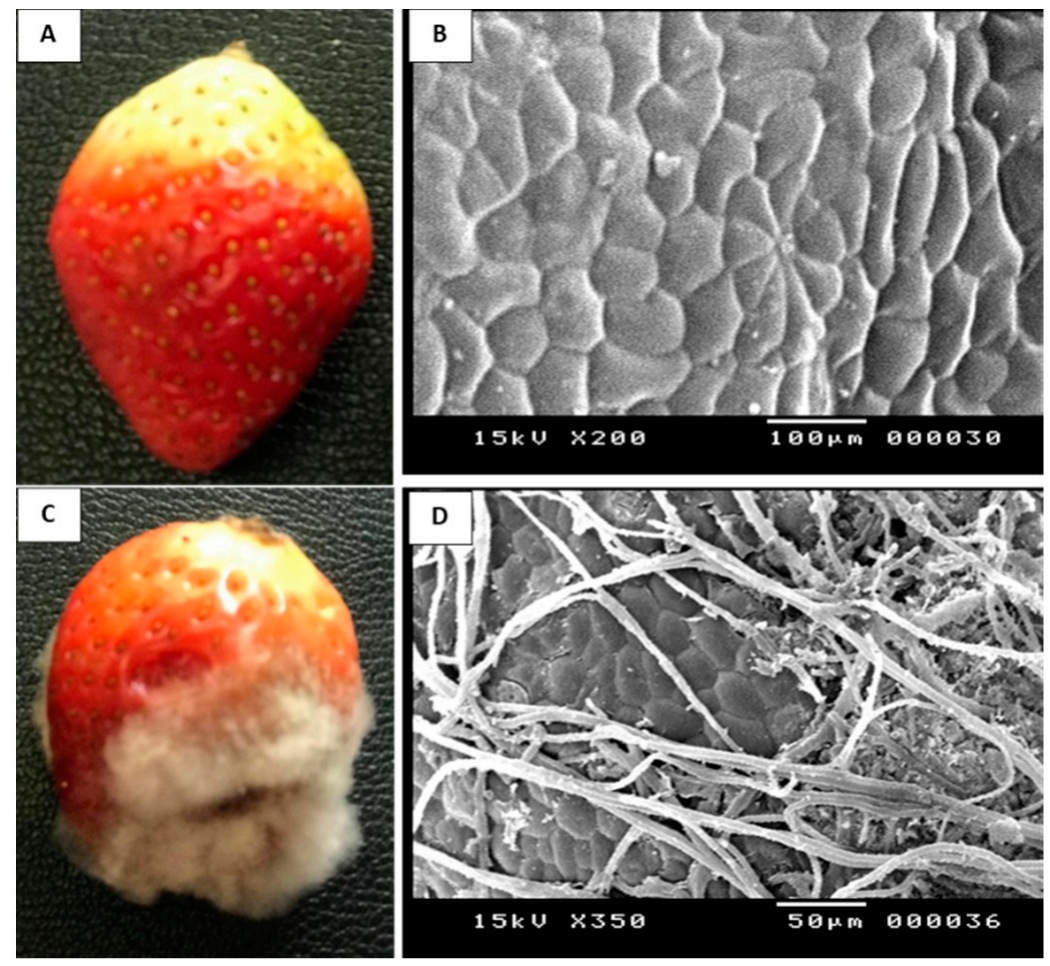

Figure 2. Scanning electron micrographs illustrating a comparison between healthy strawberry fruit and those infected with B. cinerea Str5. Healthy strawberry fruit show a smooth surface without fungal colonization (A,B); however, the infected fruit (C,D) show the intensive occurrence of hyphae on the fruit surface.

\subsection{Fungicidal Effect of Preen Oil against B. cinerea Str5}

The quantity of extractable preen (uropygial) oil from white chicken feathers was $9.43 \mathrm{mg} / \mathrm{g}$ of feathers. The fungicidal effect of different concentrations of extractable preen oil was estimated against $B$. cinerea Str5, and revealed a significant reduction $(p<0.05)$ in both radial growth and colony-forming fungal units of the pathogen (Figures 3 and 4 ). The obtained results indicate that the minimum inhibitory concentration (MIC) of the tested preen oil was $25 \mu \mathrm{L} / \mathrm{mL}$, which reduced the radial growth of $B$. cinerea Str5 by $41.3 \%$ compared to the control, and decreased the colony-forming units by $28.6 \%$. On the other hand, when increasing the concentration of preen oil, a significant decrease $(p<0.05)$ in fungal radial growth and the number of colony-forming units was observed (Figures 3 and 4). Accordingly, the concentration of $25 \mu \mathrm{L} / \mathrm{mL}$ of preen oil was used as the minimum inhibitory concentration to reduce the severity of the Botrytis grey mold on strawberries in vivo.

\subsection{Chemical Analysis of the Preen Oil Extract}

The analysis of preen oil composition using GC/MS revealed that this oil contains 17 fractions (Figure 5), which were recorded as the main constituents, and accounted for $79.3 \%$ of the total obtained analytes (Table 1). The most common components were hexadecenoic acid $(14.79 \%)$, heptadecanoic acid $(4.74 \%)$, octadecanoic acid $(15.93 \%)$, methyl 18-methylnonadecanoate (8.40\%), dodecanoic acid (6.01\%), and 1,2-benzenedicarboxylic acid $(4.34 \%)$, whereas 1,3-dimethyl-benzene, octamethyl cyclotetrasiloxane, 1-chloro-4methyl-benzene, methyl 12-methyl-tridecanoate, 9,12-octadecadienoic acid (Z,Z)-, trans13-octadecenoic acid, octadecanoic acid-17-methyl-, methyl 14-methyl-eicosanoate, 9,10dichloro-octadecanoic acid, methyl 20-methyl-heneicosanoate, and methyl 14-methyleicosanoate were recorded at 1.78, 1.90, 3.25, 1.75, 1.02, 2.88, 2.27, 1.43, 2.78, 3.35, and $2.69 \%$, respectively. 


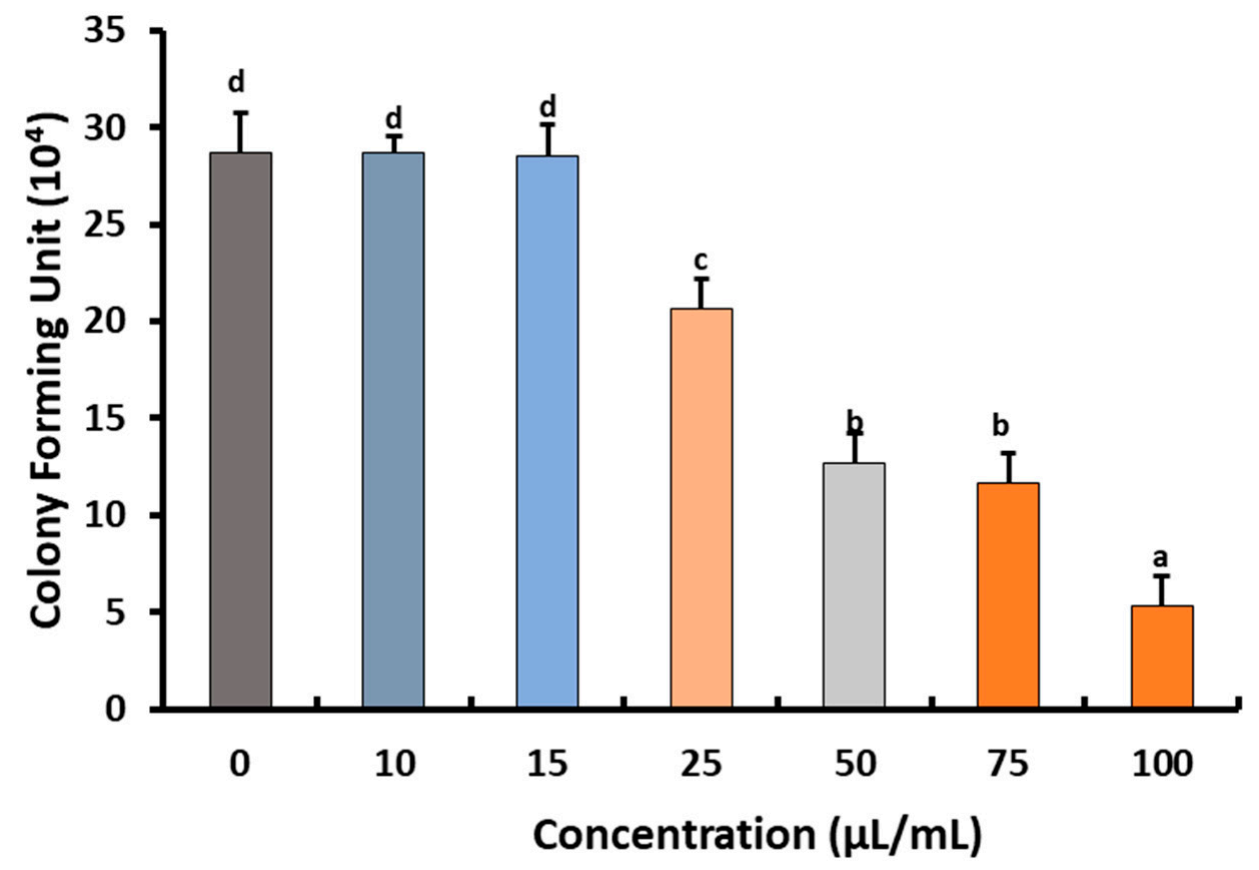

Figure 3. Impacts of different concentrations of preen oil on B. cinerea Str5 growth in terms of colonyforming units. Vertical bars represent the standard error $(n=3)$. Columns followed by the same letter are not significantly different at $p<0.05$.

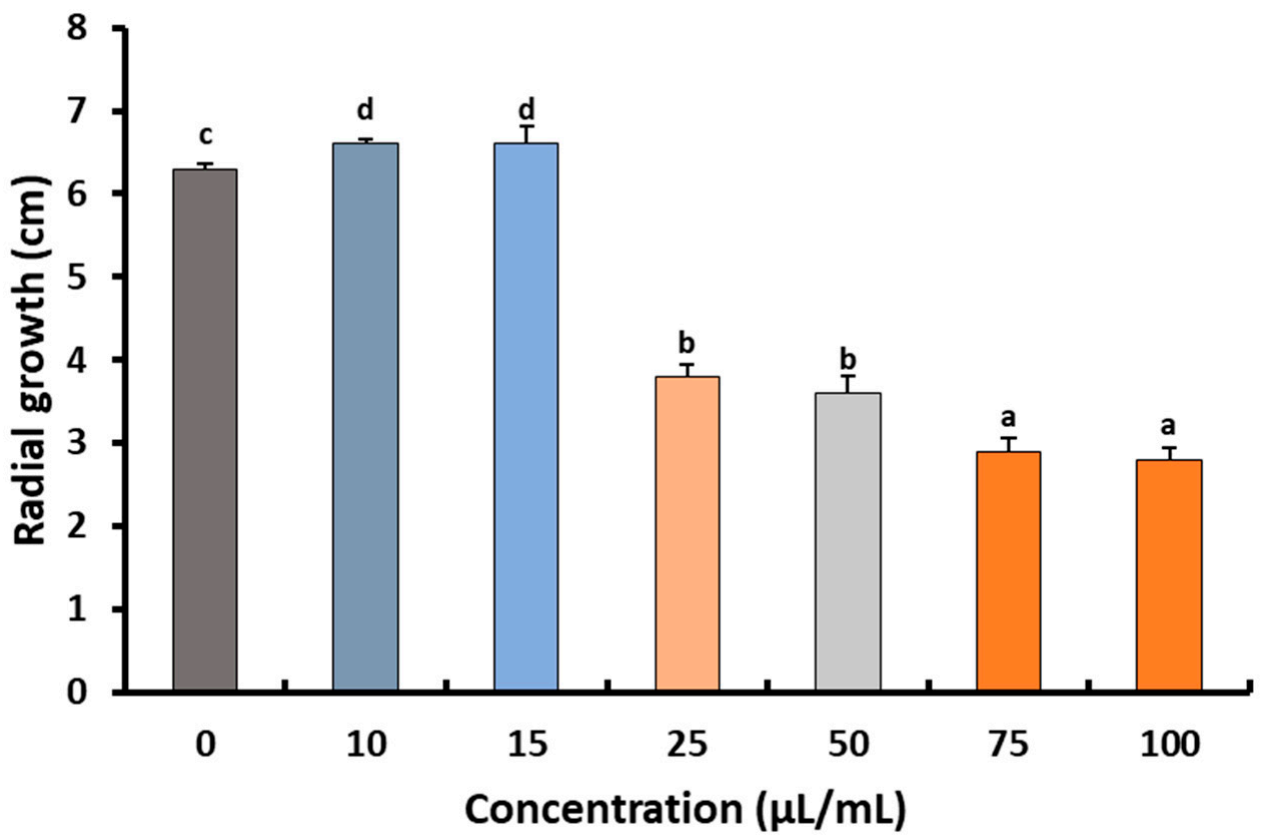

Figure 4. Impacts of different concentrations of preen oil on B. cinerea radial growth. Vertical bars represent the standard error $(n=3)$. Columns followed by the same letter are not significantly different at $p<0.05$. 


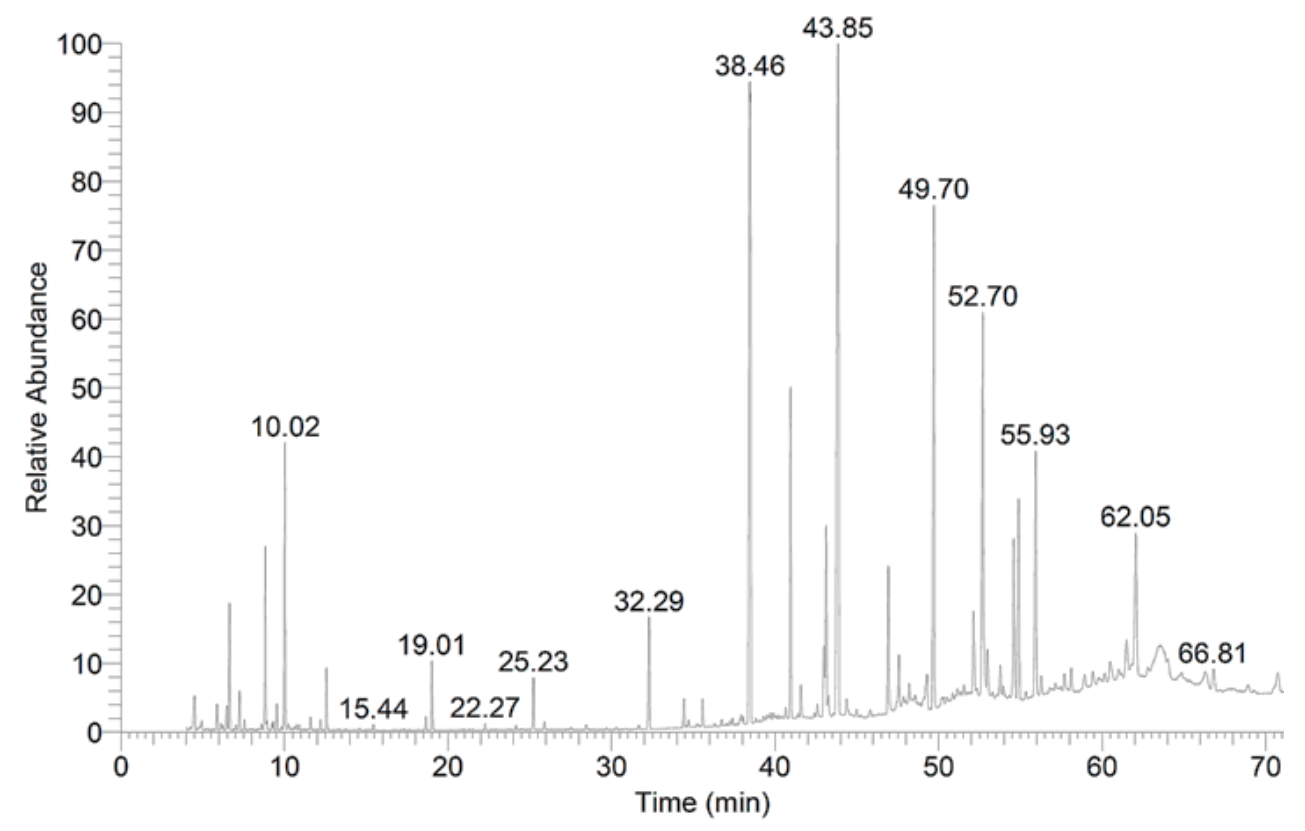

Figure 5. GC/MS profile of preen oil composition.

Table 1. The components of preen oils extracted from chicken feathers.

\begin{tabular}{ccc}
\hline RT & The Components & \% of Total Constituents \\
\hline 6.65 & Benzene, 1,3-dimethyl- & 1.78 \\
8.83 & Cyclotetrasiloxane, octamethyl- & 1.90 \\
10.02 & Benzene, 1-chloro-4-methyl- & 3.25 \\
32.29 & Methyl 12-methyl-tridecanoate & 1.75 \\
38.46 & Hexadecanoic acid & 14.79 \\
40.95 & Heptadecanoic acid & 4.74 \\
42.99 & 9,12-Octadecadienoic acid (Z,Z)- & 1.02 \\
43.12 & trans-13-Octadecenoic acid & 2.88 \\
43.86 & Octadecanoic acid & 15.93 \\
46.93 & Octadecanoic acid, 17-methyl- & 2.27 \\
49.70 & Methyl 18-methylnonadecanoate & 8.40 \\
52.13 & Methyl 14-methyl-eicosanoate & 1.43 \\
52.70 & Dodecanoic acid & 6.01 \\
54.60 & Octadecanoic acid, 9,10-dichloro- & 2.78 \\
54.89 & Methyl 20-methyl-heneicosanoate & 3.35 \\
55.93 & 1,2-Benzenedicarboxylic acid & 4.34 \\
62.05 & Methyl 14-methyl-eicosanoate & 2.69 \\
\hline
\end{tabular}

2.4. Screening for Antagonistic Activity of Endophytic Bacteria against B. cinerea Str5 Growth In Vitro

Out of 13 endophytic bacterial isolates obtained from asymptomatic strawberry fruit, 9 bacterial isolates showed an antagonistic potential against $B$. cinerea Str5. The highest antagonistic activity was recorded in the case of isolate B3, giving a clear zone of $0.7 \mathrm{~cm}$, followed by endophytic bacterial isolate B11 $(0.5 \mathrm{~cm})$, and then by endophytic bacteria B5 and B13, each recording a clear zone of $0.4 \mathrm{~cm}$ (Figure 6). The most prevalent antagonistic bacterial isolate B3 was selected for further in vivo experiments, and was identified based on the morphology of the colony, microscopic, and biochemical characteristics, while the $16 \mathrm{~S}$ rRNA gene phylogenetic analysis was assessed. The endophytic bacteria displayed positive reactions to fructose, citrate, sorbitol, glycerol, glucose, maltose fermentation, gelatin, casein hydrolysis, and catalase production. On the other hand, the isolated bacteria exhibited negative reactions to galactose fermentation (Table 2). The 16S rRNA partial sequence of 1397 base pairs of antagonistic bacterial isolate B3 showed a 98.73\% similarity 
in Bacillus safensis BSKr1 (LN999937). Consequently, based on the phenotypic and genotypic characterization, the antagonistic bacterial strain B3 was identified as B. safensis, and the obtained sequence was deposited in GenBank under the accession number OK533668. The phylogenetic reconstruction of a 16S rRNA dataset is shown in Figure 7.

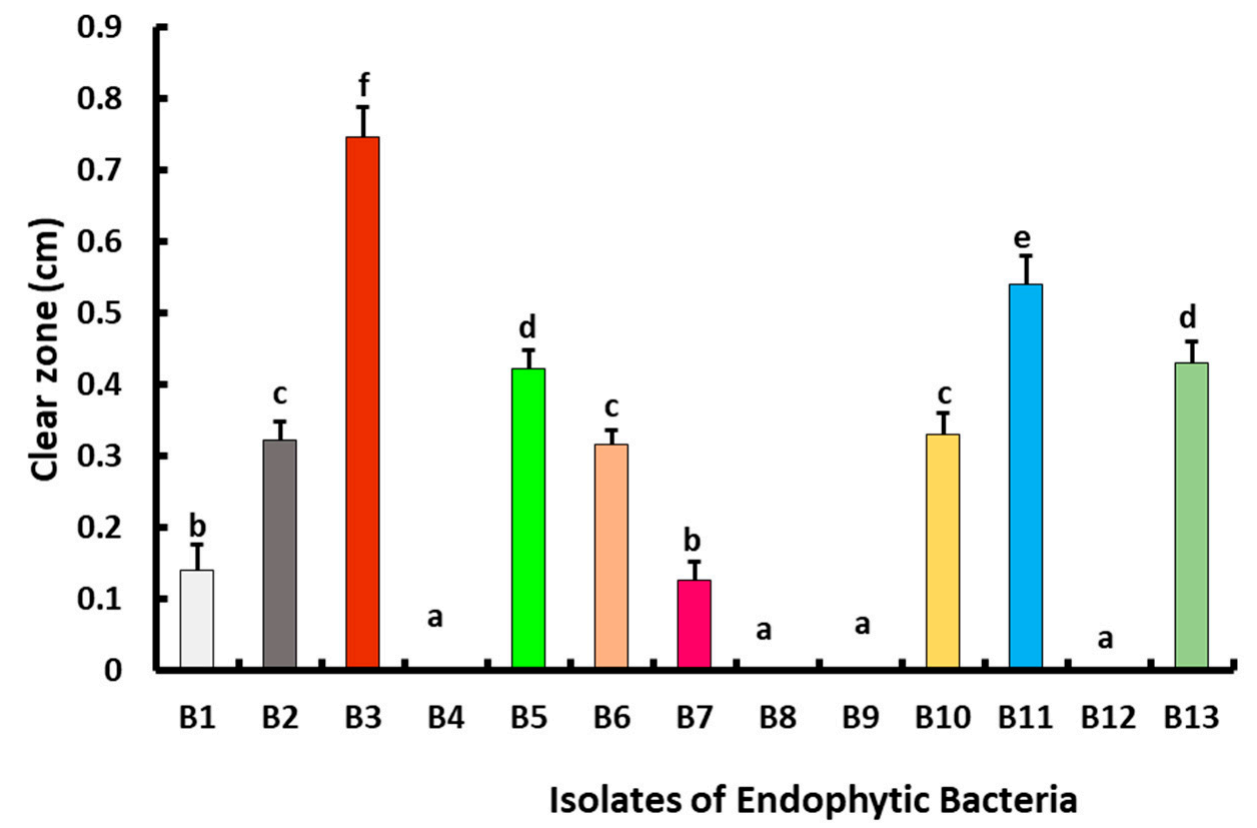

Figure 6. Antagonistic activities of isolated endophytic bacteria against B. cinerea Str5. Vertical bars represent the standard error $(n=3)$. Columns followed by the same letter are not significantly different at $p<0.05$.

Table 2. Colonial and biochemical characteristics of the most antagonistic bacterium B. safensis B3.

\begin{tabular}{|c|c|}
\hline Biochemical Test & Value \\
\hline \multicolumn{2}{|c|}{ Colonial characteristics } \\
\hline Gram staining & $+^{*}$ \\
\hline Colony color & White \\
\hline Colony shape & Round with irregular margins \\
\hline Cell shape & Rod-shaped \\
\hline \multicolumn{2}{|c|}{ Biochemical characteristics } \\
\hline \multicolumn{2}{|c|}{ Carbon source utilization } \\
\hline D-Fructose & + \\
\hline Citrate & + \\
\hline D-Sorbitol & + \\
\hline D-Galactose & - \\
\hline Glycerol & + \\
\hline Glucose & + \\
\hline Maltose & + \\
\hline Catalase test & + \\
\hline Gelatin hydrolysis & + \\
\hline Casein hydrolysis & + \\
\hline Growth at $4{ }^{\circ} \mathrm{C}$ & - \\
\hline Growth at $37^{\circ} \mathrm{C}$ & + \\
\hline Growth at $45^{\circ} \mathrm{C}$ & + \\
\hline
\end{tabular}

* +: positive reaction; -: negative reaction. 


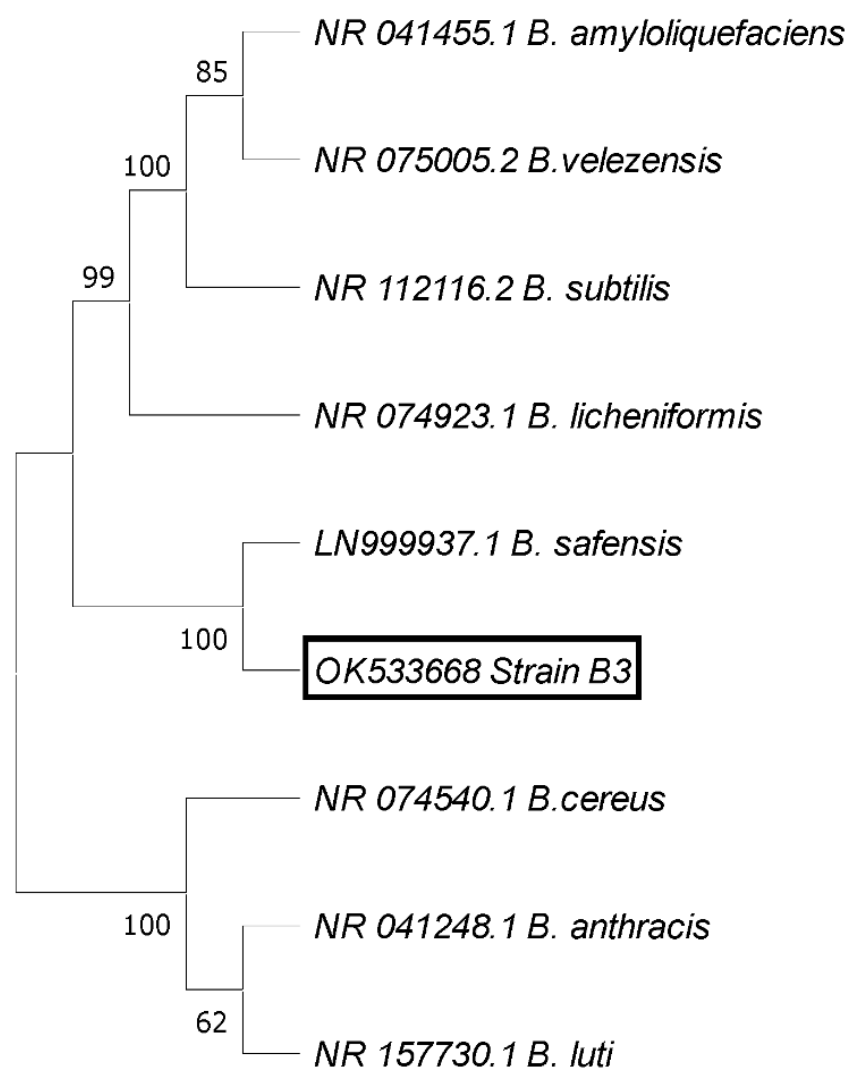

Figure 7. Phylogenetic tree of the most antagonistic bacterial strain B3. The strain is aligned in the clade with B. safensis, with $100 \%$ similarity. The evolutionary history was inferred using the UPGMA method. The evolutionary distances were computed using the maximum composite likelihood method, and are in the units of the number of base substitutions per site.

\subsection{Hydrolytic Enzyme Activity of Antagonistic Bacteria}

The obtained data in Table 3 show that the endophytic bacterium B. safensis B3 had the potential to produce hydrolytic enzymes (chitinase, lipase, and protease) that are responsible for the hydrolysis of the $B$. cinerea Str5 cell wall, and consequently restrict the fungal growth and spread in the culture medium. The activity of chitinase enzymes produced by $B$. safensis was $3.69 \pm 0.31 \mathrm{U} / \mathrm{mL}$, and the chitinase-specific activity was $9.66 \pm 1.04 \mathrm{U} / \mathrm{mg}$ protein. The hydrolytic lipase and protease activities were $10.65 \pm 0.51$ and $13.28 \pm 0.65 \mathrm{U} / \mathrm{mL}$, respectively. The corresponding specific activities of these enzymes were $16.45 \pm 3.55$ and $18.85 \pm 3.26 \mathrm{U} / \mathrm{mg}$ protein, respectively (Table 3).

Table 3. Enzymatic activities of the endophytic bacterium B. safensis B3.

\begin{tabular}{cccc}
\hline Enzyme & $\begin{array}{c}\text { Enzyme Activity } \\
\mathbf{( U / m L )}\end{array}$ & $\begin{array}{c}\text { Protein } \\
\text { Concentration } \\
(\mathbf{m g} / \mathbf{m L})\end{array}$ & $\begin{array}{c}\text { Enzyme-Specific } \\
\text { Activity (U/mg Protein) }\end{array}$ \\
\hline Chitinase & $3.69 \pm 0.31^{*}$ & $0.340 \pm 0.29$ & $9.66 \pm 1.04$ \\
Protease & $13.28 \pm 0.65$ & $0.705 \pm 0.20$ & $18.85 \pm 3.26$ \\
Lipase & $10.65 \pm 0.51$ & $0.650 \pm 0.14$ & $16.45 \pm 3.55$ \\
\hline
\end{tabular}

* Value represents the standard error $(n=3)$.

2.6. Efficiency of B. safensis B3 and/or Preen Oil in the Control of Postharvest B. cinerea Str5 Grey Mold on Strawberries, and Consequent Impact on the Fruit

2.6.1. Disease Severity

The data in Table 4 show that $B$. cinerea Str5-infected strawberry fruit recorded a disease severity of $86.11 \pm 8.1 \%$, whereas the application of B. safensis B3 and preen oil- 
individually or in combination-decreased the disease severity of B. cinerea Str5 grey mold on strawberry fruits significantly $(p<0.05)$ in vivo (Figure 8$)$. The highest reduction in disease severity was recorded by preen oil $(87.25 \%)$, followed by the application of B. safensis $(86.52 \%)$. However, the combinations of both treatments did not show any stimulation of the biocontrol efficiency, but the reduction in the disease severity was lower than that caused by either of the individual treatments, at $77.28 \%$ (Table 4).

Table 4. Impact of B. Subtilis and preen oil on postharvest Botrytis grey mold severity.

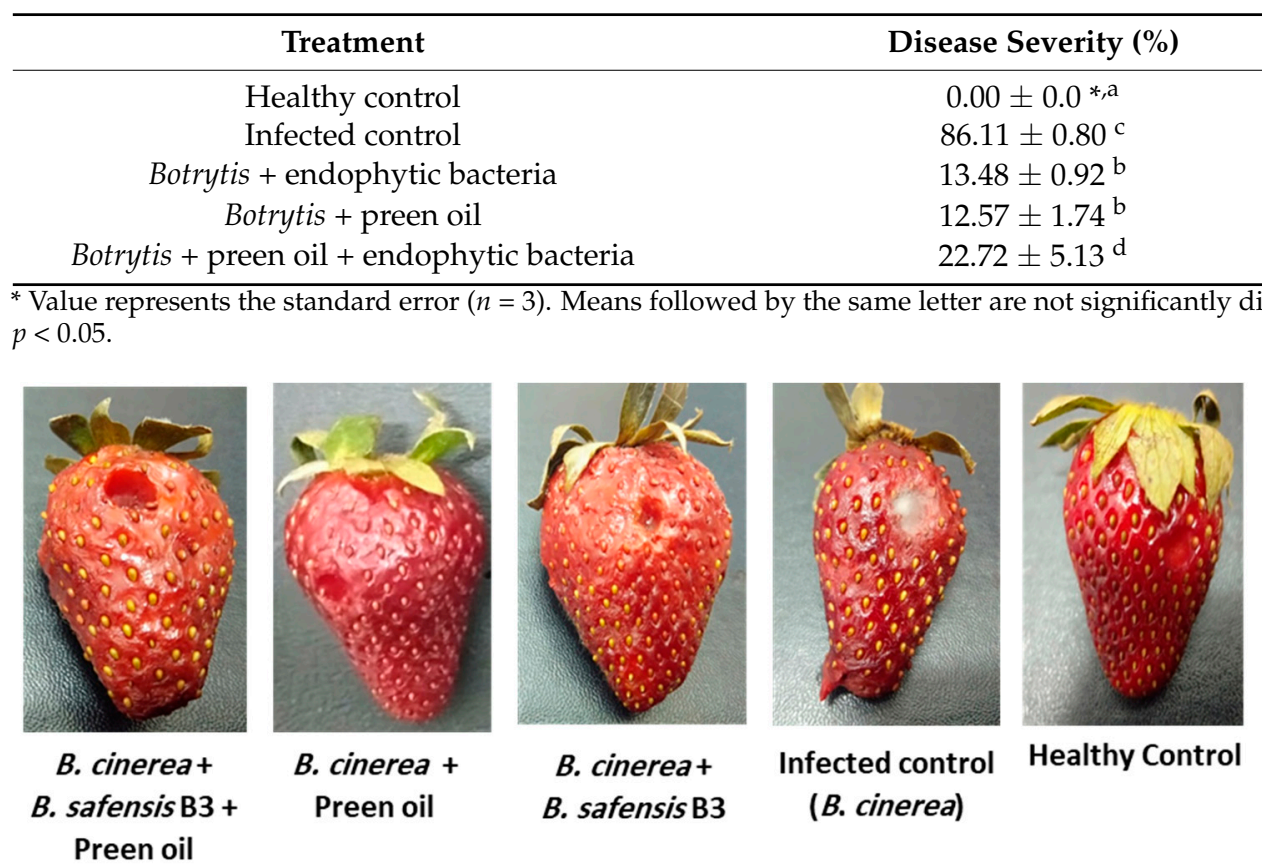

Figure 8. Fruit treatments with preen oil and/or Bacillus safensis B3 compared with untreated fruit (healthy control) and fruit infected only with B. cinerea Str5 (infected control).

\subsubsection{Biochemical Analysis}

Total Phenolics

The data in Figure 9 reveal that both B. safensis and preen oil significantly increased the total phenol contents of infected strawberry fruit when applied either individually or in combination $(p<0.05)$, compared to the healthy or the infected control fruit.

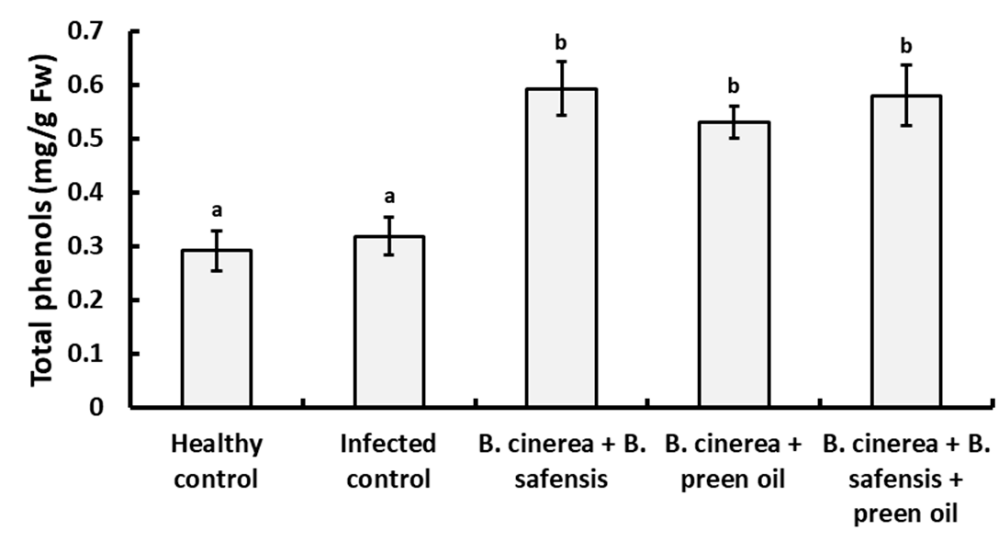

Treatments

Figure 9. Effects of different treatments on total phenols in strawberry fruit. Vertical bars represent the standard error $(n=3)$. Columns followed by the same letter are not significantly different at $p<0.05$. 


\section{Antioxidant Enzymes}

The obtained results display the activity of antioxidant enzymes attributed to the applied bioagents endophytic $B$. safensis and preen oil, individually or in combination, in the infected strawberry fruit (Figure 10). The infected strawberry fruit showed a remarkable decrease in superoxide dismutase (SOD) compared with the healthy fruit, whereas the infected fruit inoculated with the bioagents displayed a significant increase $(p<0.05)$ in the SOD activity compared with fruits infected only with B. cinerea Str5 (Figure 10A). On the other hand, the inoculation of infected strawberry fruit with B. safensis B3 showed a significant increase $(p<0.05)$ in catalase (CAT) activity compared with other treatments (Figure 10B). Furthermore, the application of the bioagents increased the ascorbate peroxidase (APX) activity significantly $(p<0.05)$ compared with infected strawberry fruit (Figure 10C). Infection of strawberry fruit with B. cinerea Str5 exhibited a high enzyme activity of peroxidases (PO) compared with healthy fruits (Figure 10D), whereas the application of the bioagents decreased the activity of peroxidases compared with infected strawberry fruit.
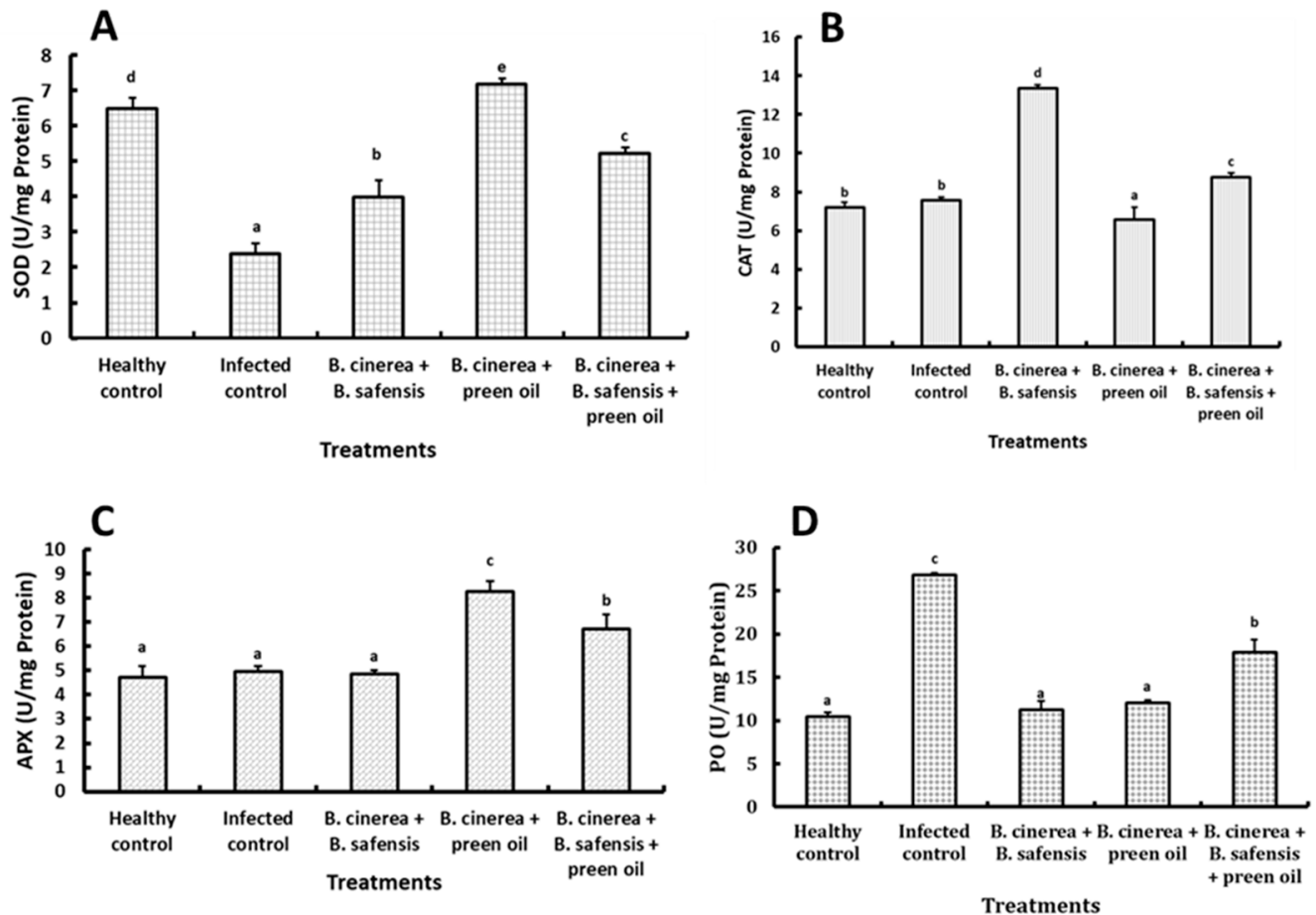

Figure 10. Effects of different treatments on antioxidant activities of superoxide dismutase (SOD) (A), catalase (CAT) (B), ascorbate peroxidase (APX) (C), and peroxidase (PO) (D) in strawberry fruit. Vertical bars represent the standard error $(n=3)$. Columns followed by the same letter are not significantly different at $p<0.05$.

\section{Discussion}

In this study, Botrytis cinerea Str5 was isolated from strawberry fruit with grey mold disease. The pathogenicity test of $B$. cinerea Str5 showed a high disease severity on the strawberry fruit with a high level of fungal colonization. Botrytis cinerea is considered to be one of the most problematic necrotrophic pathogens in the fruit sector, especially in the storage stage, as more than 586 plant species can be infected by this necrotrophic fungus [21] resulting in an economic loss of millions of USD. Annually, millions of USD are spent for the control of this fungus via chemical fungicides [22]. Due to economic and environmental concerns, as well as fungicide resistance [23], there is an urgent need for alternative strategies for $B$. cinerea control. This study explored the biocontrol efficacy of the novel and eco-friendly bioagents preen oil and endophytic Bacillus safensis for controlling postharvest Botrytis grey mold in strawberry fruit. 
The fungicidal effects of different concentrations of preen oil against B. cinerea Str5 showed a significant reduction in both radial growth and colony-forming units of the pathogen. Our findings are supported by those of Alt et al. [24], who reported that the preen oil extracted from the uropygial glands of birds acts as an important line of defense against harmful microorganisms. Interestingly, some studies have investigated the applicability of preen oil as an antimicrobial agent and to prevent attack from parasites and pathogens [25,26]. Moreover, Cook et al. [27] reported that purified preen oil can be used as a safe human food and animal feed additive to provide benefits for human and animal health, with many applicable medicinal properties [27]. Recently, there has been great interest in the application of bioactive compounds for controlling fungal pathogens on pre- and postharvest crops and food products, because these bioactive compounds are renewable, safe for humans, and eco-friendly [28]. Although there are many studies concerning the investigation of the fungicidal activity of plant extracts and essential oils against various pathogenic fungi [29], no studies have been performed to assay the bioactivity of preen oil extracted from birds' feathers in controlling phytopathogenic fungi. Consequently, the current study is considered a pioneer in discovering the biofungicidal effect of preen oil against $B$. cinerea $\operatorname{Str} 5$ diseases in strawberries. Additionally, the quantity of extractable oil from chicken feathers was $9.34 \mathrm{mg} / \mathrm{g}$ of feathers. This could encourage the application of the oil as an innovative strategy to manage postharvest disease in strawberries on a commercial scale.

The GC/MS analysis of preen oil revealed the presence of many fatty acids, lipids, and other hydrocarbon components, e.g., hexadecenoic, heptadecanoic, dodecanoic, and 9,12-octadecadienoic acids, as well as methyl nonadecanoate, methyl eicosanoate, and 1,3dimethyl-benzene. Interestingly, Lattanzio et al. [30] stated that the component dimethoxybenzoic acid and its derivative compounds exhibited an important role in the suppression of $B$. cinerea postharvest diseases [31]. Additionally, fatty acids of the phospholipids are vital constituents of the two-layered lipids in the cell membrane, which retains the cell structure and integrity [32]. Furthermore, these phospholipids play an important role in controlling mechanisms of plant diseases-either directly, by involving the components in inducing disorders and damages into the plasma membranes, or indirectly, by preventing the biosynthesis pathways of fatty acids that target the plasma membrane phospholipids [32]. Moreover, the polyunsaturated 9,12-octadecadienoic acid (linoleic acid, 18:2) showed antifungal properties against many plants' pathogenic fungi [33]. Consequently, the chemical analysis of the preen oil obtained from GC/MS revealed that this extracted oil has potential antifungal activity against the Botrytis postharvest diseases and, for that reason, preen oil could be applied as a new and innovative strategy for prospective applications in agricultural technologies and food safety.

Furthermore, there is currently great interest in searching for antagonistic strains that have biocontrol potential for postharvest diseases caused by bacteria, yeasts, or fungi [34,35]. Moreover, there is still a great need for new effective microbial species from unexploited environments that could act as biocontrol agents. In the present study, the endophytic bacterium Bacillus safensis B3 exhibited the highest antagonistic activities against $B$. cinerea Str5; consequently, it was chosen to evaluate the potential to produce fungal cell-wall-hydrolyzing enzymes and their capability to reduce Botrytis grey mold severity in vivo. Antagonistic endophytic bacteria are ubiquitous microbial agents that can colonize and inhabit the interior asymptomatic plant tissues without triggering any harmful impacts [36,37], displaying intimate interactions with the host plant; as such, they receive considerable attention as biocontrol agents, and provide protection against postharvest diseases [38,39]. Many authors have revealed that Bacillus safensis is considered to be a plant-host-dwelling endophytic bacterium, and showed important sources for innovative applications including recyclable microbial enzymes, drug delivery, synthetic biology, and bioactive metabolites that are crucial for numerous biotechnological applications [40,41]. Remarkably, Wu et al. [41] stated that B. safensis isolated from Chloris virgata root showed a high potential for hydrocarbon degradation and plant-growth activities. On the other hand, 
B. pumilus and B. safensis are considered to be the most widespread and significant soil bacterial species within the B. pumilus group [42], and exhibit potent biotechnological applications, such as in probiotics and phytosanitary-based products [43,44]. Lateef et al. [45] stated that $B$. safensis is considered to be a safe industrial candidate due it being harmless to humans, producing no toxic metabolic byproducts, and retaining a potent secretion system for extracellular proteins. Due to these features, B. safensis may find feasible applications in medicine, agriculture, and other industries, including probiotics, amino acids, and vitamins. Based on these findings, $B$. safensis could be used as a safe biocontrol agent against postharvest fruit diseases.

Interestingly, the endophytic bacterium B. safensis B3 had the potential to produce hydrolytic enzymes (chitinase, lipase, and protease) that are responsible for the hydrolysis of the B. cinerea Str 5 cell wall, consequently restricting fungal growth. One of the proposed mechanisms for the biological control of fungal infections and plant pathogen inoculum potential is the degradation of pathogens' cell walls by hydrolytic enzymes [46,47]. The ability of the endophytic bacterial isolate $B$. safensis to produce hydrolytic enzymes revealed its potential as a biocontrol agent against pathogenic fungi. Similar to our results, many biocontrol microorganisms have shown the potential to produce cell-wall-degrading enzymes (chitinase, lipase, protease, and CMCase), such as Trichoderma spp. [48], Wickerhamomyces anomalus [49], Talaromyces pinophilus [50], and Bacillus subtilis [47]. Bacillus safensis is found in various environments, and shows diverse benefits for plant growth, showing plant-growth-promoting activities, antagonistic activities against fungal growth, and the ability to reduce the growth of phytopathogens [51]. Consequently, the capability of the endophytic bacterium $B$. safensis to produce extracellular cell-wall-degrading enzymes is often used as a prevalent indicator for its pathogen-antagonistic characteristics [52,53].

In the present study, B. cinerea Str5 showed a disease severity of $86.11 \pm 8.1 \%$ in infected strawberry fruit, whereas the application of the bioagents B. safensis B3 and preen oil individually decreased the disease severity of $B$. cinerea Str5 grey mold on strawberry fruit in vivo by $87.25 \%$ and $86.52 \%$, respectively. Meanwhile, the combination of both bioagents did not show any stimulation of the biocontrol efficiency. We assume that the negative impact of the mixture could be because the preen oil has an inhibitory effect on $B$. safensis in some ways that could obscure or inhibit the efficiency of the bacteria. The main implication of these results is that in practice, and from the economic point of view, either the preen oil or B. safensis may be used separately, while their combination should be avoided.

Furthermore, the in vivo application of either B. safensis or preen oil increased the total phenols, superoxide dismutase (SOD), and ascorbate peroxidase (APX) activity in infected fruit compared to the healthy or the infected strawberry fruit. Additionally, the inoculation with preen oil led to a significant decrease in catalase (CAT) enzyme activity in infected strawberry fruit, whereas the application of the preen oil and B. safensis decreased the activity of peroxidases. The increase in phenolic contents in strawberry tissues may indicate the strength of plant resistance against Botrytis grey mold [54] due to the enhancement of the strawberry cell wall's mechanical strength [55], in addition to the reductions in water permeability and apoplastic solute conductance that lead to increased cell resistance against pathogens [56]. Osbourn [57] stated that the deposition of phenolics may be toxic to the phytopathogens that act as substrates for oxidative reactions producing toxic quinones [58], as well as increasing the plant resistance due to changing the $\mathrm{pH}$ value of the cells' cytoplasm, and subsequent inhibition of the fungal pathogens [59]. Interestingly, the changes in the antioxidant enzymes' activity elucidate the role of the bioagents in the enhancement of the plant defense system through detoxification of toxic reactive oxygen species (ROS) that are initiated by the infection process. The infection process with the pathogenic fungi may be associated with prompt peroxidase activity (PO) [60] and, consequently, induced plant defense strategies, including lignin biosynthesis, deposition of plant cell walls, and reactive oxygen species generation [61]. Consequently, the antioxidants APX and CAT may play a pioneering role in scavenging hydrogen peroxides [62]. 


\section{Materials and Methods}

\subsection{Plant Materials}

Strawberry fruit (Fragaria ananassa Duch.) infected with Botrytis grey mold were collected from commercial markets in the city of Assiut, Egypt, and Abha city, Saudi Arabia, in sterile bags and transferred to the laboratory for isolation of the fungal pathogen.

\subsection{Isolation of Fungal Pathogen}

The pathogenic fungus (B. cinerea Str5) was isolated from the infected strawberries via surface sterilization, as described by Abdel-Hafez et al. [63]. The collected fruit were washed several times with tap water and then rinsed with sterilized water. Small pieces of infected parts, $\sim 1 \mathrm{~cm}^{2}$ in size, were surface-sterilized using $70 \%$ ethanol for $1 \mathrm{~min}$, $2 \%$ sodium hypochlorite for $1 \mathrm{~min}$, and $70 \%$ ethanol for $30 \mathrm{~s}$. Finally, the pieces were washed with sterilized $\mathrm{H}_{2} \mathrm{O}$ and air-dried under sterilized conditions [63]. The sterilized fruit pieces were inoculated on the surface of potato dextrose agar (PDA) medium and incubated at $25 \pm 2{ }^{\circ} \mathrm{C}$ until fungal growth. The growing pathogen was purified on PDA plates and identified based on the determination of its morphological features in terms of single-spore cultures as well as microscopic features of conidia and conidiophores [64], and then it was preserved and maintained on a PDA slant at $4{ }^{\circ} \mathrm{C}$ in the culture collections of the mycological herbarium under culture number Str5 in the Botany and Microbiology Department, Faculty of Science, Assiut University.

\subsection{Assay for Pathogenicity Test of B. cinerea Str5 on Strawberry Fruit}

To verify the pathogenicity of the fungal pathogen, the recovered fungal isolate was used as an inoculum to infect healthy strawberry fruit, in order to estimate its ability to cause Botrytis grey mold disease. Visually healthy fruit were washed with distilled $\mathrm{H}_{2} \mathrm{O}$ and then sterilized with $70 \%$ ethanol for $3 \mathrm{~min}$, followed by washing with sterilized distilled water and air-drying under sterilized conditions. A sterilized cork borer $(0.5 \mathrm{~cm}$ in diameter) was used to make three wounds on healthy fruit. Then, $50 \mu \mathrm{L}$ of B. cinerea Str5 conidial suspension $\left(10^{7}\right.$ conidia $/ \mathrm{mL}$ ) was inoculated into each wound. Healthy strawberry fruit with wounds exposed to $50 \mu \mathrm{L}$ of sterile distilled $\mathrm{H}_{2} \mathrm{O}$ were used as controls. The inoculated fruit were incubated at $25 \pm 2{ }^{\circ} \mathrm{C}$ in sterile plastic boxes containing sterilized wetted cotton for 7 days. For each treatment, 3 fruit were used as replicates. The disease virulence of the tested fungal isolate was identified by the development of Botrytis grey mold fungus on infected healthy fruit [65].

\subsection{Scanning Electron Microscopy Examination}

Small pieces from healthy and infected strawberry fruit were fixed in $2 \%$ glutaraldehyde solution in $50 \mathrm{mM}$ phosphate buffer solution, $\mathrm{pH} 7.2$, and preserved at room temperature [66]. The samples were investigated using a scanning electron microscope (JEOL JSM-5400 LV, 15 KV) at the Electron Microscopy Unit, Assiut University, Egypt. All of the obtained images were computer-processed.

\subsection{Preparation and Assay of Biocontrol Agents}

\subsubsection{Preen Oil}

Extraction and Fungicidal Activity of Preen Oil

White chicken feathers were collected from slaughterhouses in Assiut, Egypt, and then washed with cold sterile water, before being air-dried for 2 days. For extracting preen oil, $100 \mathrm{~g}$ of dried white chicken feathers was added to $200 \mathrm{~mL}$ of extracting solvent (chloroform:methanol 2:1) and then shaken at $120 \mathrm{rpm}$ for $24 \mathrm{~h}$. The mixture was filtered using a porcelain funnel at room temperature. The supernatant was centrifuged at $6000 \mathrm{rpm}$ for $10 \mathrm{~min}$ in order to remove coarse particles, and then evaporated under vacuum to obtain a volume of $5 \mathrm{~mL}$ and, finally, sterilized using a Seitz bacterial filter $(0.22 \mu \mathrm{m})$. The collected extracts were preserved in sterilized brown vials at $4{ }^{\circ} \mathrm{C}$ until being used for assaying their biocontrol potential against B. cinerea Str5 [67]. For investigation of the fungicidal activity 
of preen oil, the disk diffusion technique was used [68]. Sterilized disks (6 mm) were loaded with $100 \mu \mathrm{L}$ of the extracted preen oil and were placed in $9 \mathrm{~cm}$ PDA plates seeded with the fungal pathogen $\left(10^{7}\right.$ conidia $\left./ \mathrm{mL}\right)$. Sterile n-hexane-loaded disks were used as controls, and then the plates were incubated at $28 \pm 1{ }^{\circ} \mathrm{C}$ for 7 days. The antagonistic effect of the oil extract was assessed by measuring the diameter of the inhibition zones (mm) as described by Andrews [69]. The assays were performed in triplicate.

Effects of Preen Oil on the Fungal Pathogen (Linear Growth and Fungal Colony-Forming Units)

The antagonistic effect of preen oil was estimated in vitro against $B$. cinerea Str5, by mixing $20 \mathrm{~mL}$ of potato dextrose agar (PDA) medium with different concentrations of the preen oil $(10,15,25,50,75$, and $100 \mu \mathrm{L} / \mathrm{mL})$. The PDA plates were inoculated with $5 \mathrm{~mm}$ diameter B. cinerea Str5 agar disks (7-day-old culture). Three plates were used as replicates for each concentration [70], and PDA plates without the preen oil were used as controls. After 7 days of incubation, the reduction percentage of the B. cinerea Str5 linear growth was measured as described by Bouziane et al. [71]. For estimation of the fungal colony-forming units grown on each prepared concentration $(10,15,25$, $50,75$, and $100 \mu \mathrm{L} / \mathrm{mL}), 1 \mathrm{~mL}$ of fungal spores $\left(10^{7}\right.$ conidia $\left./ \mathrm{mL}\right)$ was spread on the surface of PDA plates (amended with rose bengal) containing preen oil. The inoculated plates were incubated at $25 \pm 2^{\circ} \mathrm{C}$ for 7 days, and then the growing fungal colonies were estimated as colony-forming units $(\mathrm{CFU} / \mathrm{mL})$. Three plates were used as replicates for each concentration. Minimum inhibitory concentration (MIC) was estimated as the lowest concentration of preen oil that inhibited the pathogen growth on the agar plates [19].

\section{Analysis of Preen Oil Composition}

The chemical composition of preen oil extracted from white chicken feathers was analyzed by using GC/MS (Thermo Fisher Scientific, Model: DPC-Direct Probe Controller (DPC- 20451), Waltham, MA, USA; at the Chemistry Department, Faculty of Science, Assiut University), as described by Najjar et al. [72].

\subsubsection{Antagonistic Bacteria}

Isolation of the Endophytic Bacteria

Endophytic bacterial isolates were recovered from fresh healthy strawberry fruit via surface sterilization. Healthy fruit were sterilized using $70 \%$ ethanol for $1 \mathrm{~min}$, followed by $2 \%$ sodium hypochlorite for $1 \mathrm{~min}$. Detached segments from the healthy fruit were washed with sterilized distilled water, air-dried under aseptic conditions, and then inoculated on the surface of nutrient agar plates, after which they were incubated at $28^{\circ} \mathrm{C}$ for $48 \mathrm{~h}$. The growing bacterial colonies from the margins of fruit segments were purified using the streak plate technique for single colonies [73], and then maintained on a nutrient agar slant at $4{ }^{\circ} \mathrm{C}$ in the culture collections of the Botany and Microbiology Department, Faculty of Science, Assiut University.

\section{Assay for Antagonistic Activity}

The antagonistic activity of 13 endophytic bacterial isolates (isolated from healthy strawberry fruit) against B. cinerea Str5 was assayed as described by Hashem and Alamri [65], with some modifications. The endophytic bacterial isolates were grown on nutrient agar plates seeded with B. cinerea Str5 inoculum $\left(10^{7}\right.$ conidia $\left./ \mathrm{mL}\right)$, and then incubated at $28 \pm 1{ }^{\circ} \mathrm{C}$ for 7 days. Three plates were used as replicates for each isolate. Finally, the fungal growth inhibition was assessed by the determination of the inhibition zone ( $\mathrm{mm}$ ), as measured from the edge of the fungal growth to the edge of the bacterial growth. Three replicates were used for the assay. 
Identification of the Most Antagonistic Endophytic Bacterial Isolate

The most prevalent antagonistic bacterial isolate was identified based on culture, microscopic, and biochemical tests, as described in Bergey's Manual of Systematic Bacteriology [74]. The identification of antagonistic bacteria was molecularly confirmed by amplification of the partial 16S rRNA gene, using the primers 27F and 1492R [75]. The PCR amplification was achieved in a reaction volume $(25 \mu \mathrm{L})$ containing template DNA (10-50 ng), $0.4 \mu \mathrm{M}$ of each primer, $0.75 \mathrm{U}$ of EF-Taq DNA polymerase (SolGent, Daejeon, Korea), $0.2 \mathrm{mM}$ of each d NTP (SolGent, Daejeon, Korea), and $1 \times$ EF-Taq reaction buffer (SolGent, Daejeon, Korea). The thermocycling conditions involved an initial denaturation step at $95^{\circ} \mathrm{C}$ for $15 \mathrm{~min}$, followed by 30 cycles at $95^{\circ} \mathrm{C}$ for $20 \mathrm{~s}, 50^{\circ} \mathrm{C}$ for $40 \mathrm{~s}$, and $72^{\circ} \mathrm{C}$ for $1.5 \mathrm{~min}$, with a final extension step at $72^{\circ} \mathrm{C}$ for $5 \mathrm{~min}$. The PCR product was separated by gel electrophoresis on $1.5 \%$ agarose containing ethidium bromide with a $0.5 \times$ Tris-acetate-EDTA (TAE) buffer, and visualized using a UV illuminator. The PCR product was then purified using a SolGent PCR purification kit (SolGent, Daejeon, Korea), according to the manufacturer's instructions [76]. The amplified 16S rRNA gene was sequenced using an ABI BigDye Terminator (v 3.1) cycle sequencing kit (Applied Biosystems, Foster City, CA, USA) and an ABI 373 0XL DNA analyzer (Applied Biosystems, Foster City, CA, USA). The obtained sequence was blasted against the NCBI GenBank database (https:/ / blast.ncbi.nlm.nih.gov/Blast.cgi) accessed on 10 October 2021, using the BLAST search program to evaluate the degree of DNA similarity.

Assay of Hydrolytic Activity of the Most Antagonistic Bacteria

a. Determination of chitinase activity

The chitinase activity of the most antagonistic bacterial isolate was estimated by growing the bacterial isolate in a medium [50] containing colloidal chitin, $1 \mathrm{~g} \mathrm{~L}^{-1} ;\left(\mathrm{NH}_{4}\right)_{2} \mathrm{SO}_{4}$, $1.4 \mathrm{~g} \mathrm{~L}^{-1}$; $\mathrm{NaH}_{2} \mathrm{PO}_{4}, 6.9 \mathrm{~g} \mathrm{~L}^{-1} ; \mathrm{KH}_{2} \mathrm{PO}_{4}, 2.0 \mathrm{~g} \mathrm{~L}^{-1}$; peptone, $10 \mathrm{~g} \mathrm{~L}^{-1}$; and $\mathrm{MgSO}_{4} .7 \mathrm{H}_{2} \mathrm{O}$, $0.3 \mathrm{~g} \mathrm{~L}^{-1}$ at $28^{\circ} \mathrm{C}$ for $48 \mathrm{~h}$. The reaction mixture was assayed by mixing $1 \mathrm{~mL}$ of colloidal chitin in $0.05 \mathrm{M}$ Tris- $\mathrm{HCl}$ buffer, $\mathrm{pH} 5.5$, and $1 \mathrm{~mL}$ of bacterial filtrate, and then incubated at $30^{\circ} \mathrm{C}$ for $1 \mathrm{~h}$. At the end of the incubation, $1 \mathrm{~mL}$ of 3,5-dinitrosalicylic reagent was added to the reaction mixture, and the chitinase activity was assessed by determining the increase in reducing groups [77] via spectrophotometric methods at $540 \mathrm{~nm}$, compared against a control tube (dist. $\left.\mathrm{H}_{2} \mathrm{O}\right)$. The assay was repeated thrice $(n=3)$. Chitinase enzyme units were determined as the amount of chitinase enzymes required to liberate $1 \mu \mathrm{M}$ of reducing groups ( $\mathrm{N}$-acetylglucosamine) per min [78].

b. Determination of protease activity

The protease enzyme activity of the antagonistic bacterial isolate was assayed by growing it on a sterilized broth medium containing tryptone, $10.0 \mathrm{~g} \mathrm{~L}^{-1}$; peptone, $5.0 \mathrm{~g} \mathrm{~L}^{-1}$; $\left(\mathrm{NH}_{4}\right)_{2} \mathrm{SO}_{4}, 3.0 \mathrm{~g} \mathrm{~L}^{-1} ; \mathrm{K}_{2} \mathrm{HPO}_{4}, 2.0 \mathrm{~g} \mathrm{~L}^{-1} ; \mathrm{MgSO}_{4} 0.2 \mathrm{~g} \mathrm{~L}^{-1}$; and casein, $1.0 \mathrm{~g} \mathrm{~L}^{-1}$ [79], and incubated at $28{ }^{\circ} \mathrm{C}$ for $72 \mathrm{~h}$ under shaking $(120 \mathrm{rpm})$. The reaction mixture was assayed by mixing $5 \mathrm{~mL}$ of casein solution $(1 \%)$ and $1 \mathrm{~mL}$ of bacterial filtrate by vortexing, followed by incubation in a water bath at $30^{\circ} \mathrm{C}$ for $10 \mathrm{~min}$. After that, $5 \mathrm{~mL}$ of trichloroacetic acid $(10 \%)$ was added to the reaction mixture to stop the enzymatic reaction, and then $5 \mathrm{~mL}$ of $\mathrm{Na}_{2} \mathrm{CO}_{3}$ and $1 \mathrm{~mL}$ of Folin-Ciocalteu reagent were added. Protease enzyme activity was assessed by the determination of the amount of liberated amino acids, by measuring the absorbance spectrophotometrically at $660 \mathrm{~nm}$ and using tyrosine as the standard curve. The assay was repeated thrice $(n=3)$. Protease activity units were estimated as the amount of protease enzymes required to release $1 \mu \mathrm{mol}$ tyrosine per min.

c. Determination of lipase activity

Lipase enzyme activity was estimated by the cultivation of antagonistic bacterial isolate on Tween-containing medium, including $\mathrm{K}_{2} \mathrm{HPO}_{4}, 1.5 \mathrm{~g} \mathrm{~L}^{-1}$; $\mathrm{NH}_{4} \mathrm{NO}_{3}, 1 \mathrm{~g} \mathrm{~L}^{-1}$; $\mathrm{MgSO}_{4}, 0.025 \mathrm{~g} \mathrm{~L}^{-1} ; \mathrm{CaCl}_{2}, 0.025 \mathrm{~g} \mathrm{~L}^{-1} ; \mathrm{FeSO}_{4}, 0.015 \mathrm{~g} \mathrm{~L}^{-1}$; and $\mathrm{ZnSO}_{4}, 0.005 \mathrm{~g} \mathrm{~L}^{-1}$. The $\mathrm{pH}$ was adjusted to 5.0 and the medium was supplemented with $10 \mathrm{~mL} \mathrm{~L}^{-1}$ Tween 80 [80]. 
The cultures were incubated at $28^{\circ} \mathrm{C}$ and $120 \mathrm{rpm}$ for 7 days. Lipase enzyme activity was assayed with p-nitrophenylpalmitate (pNPP), as described by Prazeres et al. [81], using a spectrophotometric method at $410 \mathrm{~nm}$. Lipase activity units $(\mathrm{U} / \mathrm{mL})$ were calculated as the amount of lipases required for the production of $1 \mu \mathrm{mol}$ nitrophenol per min. The assay was repeated thrice $(n=3)$. Enzyme-specific activity was calculated as enzyme units per mg protein, and protein concentrations of the culture were assayed as described by Lowry et al. [82].

4.6. Biocontrol Efficiency of B. safensis B3 and Preen Oil against Postharvest Botrytis Grey Mold on Strawberries In Vivo

Healthy strawberry fruit were selected and surface-sterilized with $70 \%$ ethyl alcohol and $2 \% \mathrm{NaOCl}$ solution. Then, the fruit were washed with sterile distilled water and left for drying under sterilized conditions. A sterilized cork borer was used to make an equal number of wounds (two wounds) on each strawberry fruit [83]. The wounded fruit were then inoculated with a spore suspension of $B$. cinerea $\operatorname{Str} 5\left(10^{7}\right.$ spore $\left./ \mathrm{mL}\right)$, along with the bioagents according to the following treatments: (1) strawberry fruit inoculated with $25 \mu \mathrm{L}$ of fungal spore suspension (infected control), (2) strawberry fruit inoculated with $25 \mu \mathrm{L}$ of sterilized n-hexane (healthy control), (3) strawberry fruit inoculated with $25 \mu \mathrm{L}$ of B. cinerea Str5 spore suspension and $25 \mu \mathrm{L}$ of preen oil, (4) strawberry fruit inoculated with $25 \mu \mathrm{L}$ of $B$. cinerea Str 5 spore suspension and $25 \mu \mathrm{L}$ of antagonistic bacteria $\left(10^{5} \mathrm{CFU} / \mathrm{mL}\right)$, and (5) strawberry fruit inoculated with $25 \mu \mathrm{L}$ of B. cinerea Str5 spore suspension and $25 \mu \mathrm{L}$ of preen oil $+25 \mu \mathrm{L}$ of antagonistic bacteria $\left(10^{5} \mathrm{CFU} / \mathrm{mL}\right)$. Three fruit were used as replicates for each treatment. After that, inoculated fruit were left under sterilized conditions for drying for $1 \mathrm{~h}$. Then, strawberry fruits were incubated at $25 \pm 2{ }^{\circ} \mathrm{C}$ for 7 days in a plastic box, and the relative humidity was maintained at $98 \%$.

\subsubsection{Assay of Disease Severity}

The inoculated strawberry fruit were examined to detect $B$. cinerea colonization and weighed. Then, the decayed tissues were collected, the remaining fruit parts were weighed, and the disease severity was assessed as described by Yaganza et al. [84].

Disease severity index (DSI) was determined by the following equation:

$$
\mathrm{DSI}=(\mathrm{A}-\mathrm{B} / \mathrm{A}) \times 100
$$

where A is the strawberry fruit weight with rotting, and B is the strawberry fruit weight without rotting.

\subsubsection{Biochemical Analysis of the Inoculated Strawberry Fruit}

The biochemical variations were estimated in the inoculated strawberry tissue of the previous treatments.

\section{a. Total phenol content}

Strawberry fruit segments were dipped in liquid $\mathrm{N}_{2}$ and homogenized with $80 \%$ methanol $(0.1 \% w / v)$. The fruit homogenate was centrifuged at $10,000 \mathrm{rpm}$ at $4{ }^{\circ} \mathrm{C}$ for $15 \mathrm{~min}$, and the supernatant was evaporated at $65^{\circ} \mathrm{C}$ with a rotary evaporator. The residual parts were dissolved in $80 \%$ methanol $(5 \mathrm{~mL})$. Three replicates were used for each treatment. The total phenolic content of the strawberry samples was assessed using Folin-Ciocalteu reagent, as described by Kofalvi and Nassuth, [85], and the absorbance was determined at $750 \mathrm{~nm}$. The assay was repeated thrice $(n=3)$. The total phenolic contents were expressed as $\mathrm{mg} / \mathrm{g}$ FW [86].

\section{b. Antioxidant enzymes}

One gram of strawberry fruit tissues of each treatment was milled in $10 \mathrm{~mL}$ of phosphate buffer $(100 \mathrm{Mm}, \mathrm{pH} 6.8)$ using a mortar and pestle. The resultant homogenates were centrifuged for $5 \mathrm{~min}$ at 10,000 rpm under cooling to remove solid residues. The obtained 
extract was used to determine the antioxidant enzymes. The supernatant of strawberry fruit extract was assayed for estimation of superoxide dismutase (SOD) [87], ascorbate peroxidase (APX) [88], and catalase (CAT) [89]. Peroxidase activity (PO) of strawberry samples was assayed spectrophotometrically at $436 \mathrm{~nm}$ as described by Abo-Elyousr et al. [90]. Peroxidase enzyme activity was assayed via changes in absorbance, and expressed as peroxidase-specific activity (OD $436 \mathrm{~nm} / \mathrm{mg}$ protein). The protein concentration of the strawberry extract was assayed as described by Lowry et al. [82], and bovine serum albumin (BSA) was used as a standard protein. The assay was repeated thrice $(n=3)$.

\subsection{Statistical Analysis}

The quantitative data were statistically analyzed using SPSS 22.0 (SPSS, 2013). All treatments were laid out in 3 replicates $(n=3)$. The data were initially examined for a normal distribution of errors using a Shapiro-Wilk W-test, and for the homogeneity of variance using Levene's test. Data were analyzed for the significance of variation using a one-way analysis of variance (ANOVA). Means were compared using Tukey's range test at $p<0.05[91]$.

\section{Conclusions}

This study confirmed the efficiency of preen oil as well as the endophytic B. safensis B3 in the control of Botrytis grey mold of postharvest strawberry rot caused by B. cinerea Str5. Our results can be considered to be a pioneering report on the application of preen oil in the biological control of plant diseases. The results are very promising, and encourage the application of preen oil in the management of postharvest fruit rot, instead of using microorganisms that could give the fruit an unacceptable appearance for consumers. We recommend the application of preen oil as a new and innovative strategy to keep fruit free from infection after harvesting and during large-scale commercialization. Furthermore, we recommend a test of the efficacy of preen oil on a large number of fruit crops in the future, as well as its formulation into an appropriate biofungicide.

Author Contributions: E.A.H. and N.A.N.: experimental design, methodology, software, formal analysis, data curation, writing — original draft preparation, writing - review and editing; M.H. and Y.S.M.: supervision, formal analysis, investigation, data curation, writing-review and editing; S.A.: revised the manuscript, visualization, project administration, funding acquisition. All authors have read and agreed to the published version of the manuscript.

Funding: This research was funded by the Deputyship for Research \& Innovation, Ministry of Education, Saudi Arabia, under the project number IFP-KKU-2020/2.

Institutional Review Board Statement: Not applicable.

Informed Consent Statement: Not applicable.

Data Availability Statement: The following information was supplied regarding data availability: the sequencing data of the antagonistic bacterial strain Bacillus safensis strain B3 were deposited in the NCBI (http:/ / www.ncbi.nlm.nih.gov), accessed on 10 October 2021 website under the accession numbers OK533668.

Acknowledgments: The authors extend their appreciation to the Deputyship for Research \& Innovation, Ministry of Education, Saudi Arabia, for funding this research work through the project number IFP-KKU-2020/2.

Conflicts of Interest: The authors declare no conflict of interest.

\section{References}

1. Shen, H.; Wei, Y.; Wang, X.; Xu, C.; Shao, X. The marine yeast Sporidiobolus pararoseus ZMY-1 has antagonistic properties against Botrytis cinerea in vitro and in strawberry fruit. Postharvest Biol. Technol. 2019, 150, 1-8. [CrossRef]

2. Bhaskara Reddy, M.; Belkacemi, K.; Corcuff, R.; Castaigne, F.; Arul, J. Effect of pre-harvest chitosan sprays on post-harvest infection by Botrytis cinerea and quality of strawberry fruit. Postharvest Biol. Technol. 2000, 20, 39-51. [CrossRef] 
3. Schestibratov, K.A.; Dolgov, S.V. Transgenic strawberry plants expressing a thaumatin II gene demonstrate enhanced resistance to Botrytis cinerea. Sci. Hortic 2005, 106, 177-189. [CrossRef]

4. Barakat, R.M.; Al-Masri, M.I. Effect of Trichoderma harzianum in combination with fungicides in controlling grey mould disease (Botrytis cinerea) of strawberry. Am. J. Plant Sci. 2017, 8, 651. [CrossRef]

5. Rasiukevičiūtè, N.; Rugienius, R.; Šikšnianienè, J.B. Genetic diversity of Botrytis cinerea from strawberry in Lithuania. ZemdirbysteAgric. 2018, 105, 265-270. [CrossRef]

6. Rosero-Hernandez, E.D.; Moraga, J.; Collado, I.G.; Echeverri, F. Natural compounds that modulate the development of the fungus Botrytis cinerea and protect Solanum lycopersicum. Plants 2019, 8, 111. [CrossRef] [PubMed]

7. Vorotnikova, E.; Van Sickle, J.J.; Borisova, T. The Economic value of the precision disease management system for anthracnose and Botrytis fruit rot for the Florida strawberry industry. In Proceedings of the Southern Agricultural Economics Association Annual Meeting, Birmingham, Alabama, 4-7 February 2012; p. 20.

8. Abbey, J.A.; Percival, D.; Abbey, L.; Asiedu, S.K.; Prithiviraj, B.; Schilder, A. Biofungicides as alternative to synthetic fungicide control of grey mould (Botrytis cinerea) —Prospects and challenges. Biocontrol. Sci. Technol. 2019, 29, 207-228. [CrossRef]

9. Wisniewski, M.; Droby, S.; Norelli, J.; Liu, J.; Schena, L.; Agraria, D.; Mediterranea, U.; Feo, L.; Calabria, R. Alternative management technologies for postharvest disease control: The journey from simplicity to complexity. Postharvest Biol. Technol. 2016, 122, 3-10. [CrossRef]

10. Wang, X.; Shi, J.; Wang, R. Effect of Burkholderia contaminans on postharvest diseases and induced resistance of strawberry fruits. Plant Pathol. J. 2018, 34, 403-411. [CrossRef]

11. Minova, S.; Seskena, R.; Voitkane, S.; Metla, Z.; Daugavietis, M.; Jankevica, L. Impact of pine (Pinus sylvestris L.) and spruce (Picea abies (L.) Karst.) bark extracts on important strawberry pathogens. Proc. Latv. Acad. Sci. Sect. B Nat. Exact Appl. Sci. 2015, 69, 62-67. [CrossRef]

12. Mirmajlessi, S.M.; Mand, M.; Najdabbasi, N.; Larena, I.; Loit, E. Screening of native Trichoderma harzianum isolates for their ability to control Verticillium wilt of strawberry. Zemdirbyste-Agric. 2016, 103, 397-404. [CrossRef]

13. Valiuškaitè, A.; Uselis, N.; Kviklys, D.; Lanauskas, J.; Rasiukevičiūtè, N. The effect of sustainable plant protection and apple tree management on fruit quality and yield. Zemdirbyste-Agric. 2017, 104, 353-358. [CrossRef]

14. Gilles, M.; Zhao, J.; An, M.; Agboola, S. Chemical composition and antimicrobial properties of essential oils of three Australian Eucalyptus species. Food Chem. 2010, 119, 731-737. [CrossRef]

15. Czirják, G.Á.; Pap, P.L.; Vágási, C.I.; Giraudeau, M.; Mureşan, C.; Mirleau, P.; Heeb, P. Preen gland removal increases plumage bacterial load but not that of feather-degrading bacteria. Naturwissenschaften 2013, 100, 145-151. [CrossRef]

16. Carneiro, D.; Czirják, G.Á.; Rowe, M. Innate and adaptive immune proteins in the preen gland secretions of male house sparrows. J. Avian Biol. 2020, 51, 51. [CrossRef]

17. Droby, S.; Wisniewski, M.; Macarisin, D.; Wilson, C. Twenty years of postharvest biocontrol research: Is it time for a new paradigm? Postharvest Biol. Technol. 2009, 52, 137-145. [CrossRef]

18. Chen, P.H.; Chen, R.Y.; Chou, J.Y. Screening and evaluation of yeast antagonists for biological control of Botrytis cinerea on strawberry fruits. Mycobiology 2018, 46, 33-46. [CrossRef] [PubMed]

19. Abdel-Rahim, I.R.; Abo-Elyousr, K.A.M. Using of endophytic Saccharomycopsis fibuligera and thyme oil for management of grey mold rot of guava fruits. Biol. Control. 2017, 110, 124-131. [CrossRef]

20. Wallace, R.L.; Hirkala, D.L.; Nelson, L.M. Mechanisms of action of three isolates of Pseudomonas fluorescens active against postharvest grey mold decay of apple during commercial storage. Biol. Control. 2018, 117, 13-20. [CrossRef]

21. Williamson, B.; Tudzynski, B.; Tudzynski, P.; Van Kan, J.A. Botrytis cinerea: The cause of grey mould disease. Mol. plant path. 2007, 8, 561-580. [CrossRef]

22. Hewitt, H.G. Fungicides in Crop Protection; CAB International: New York, NY, USA, 1988.

23. Mehrotra, R.S.; Aneja, K.R.; Aggarwal, A. Fungal control agents. In Environmentally Safe Approaches to Disease Control; Lewis Publishers: New York, NY, USA, 1997; pp. 111-137.

24. Alt, G.; Mägi, M.; Lodjak, J.; Mänd, R. Experimental study of the effect of preen oil against feather bacteria in passerine birds. Oecologia 2020, 192, 723-733. [CrossRef]

25. Magallanes, S.; Møller, A.P.; García-Longoria, L.; de Lope, F.; Marzal, A. Volume and antimicrobial activity of secretions of the uropygial gland are correlated with malaria infection in house sparrows. Parasites Vectors 2016, 9, 1-8. [CrossRef] [PubMed]

26. Braun, M.S.; Sporer, F.; Zimmermann, S.; Wink, M. Birds, feather-degrading bacteria and preen glands: The antimicrobial activity of preen gland secretions from turkeys (Meleagris gallopavo) is amplified by keratinase. FEMS Microbiol. Ecol. $2018,94,117$. [CrossRef] [PubMed]

27. Cook, M.E.; Sand, J.; Olson, J.M.; Barry, T.P. Wisconsin Alumni Research Foundation: Compositions containing preen oil and methods of use thereof. U.S. Patent 10,675,241, 9 June 2020.

28. Kumar, A.; Shukla, R.; Singh, P.; Prasad, C.S.; Dubey, N.K. Assessment of Thymus vulgaris L. essential oil as a safe botanical preservative against post harvest fungal infestation of food commodities. Innov. Food Sci. Emerg. Technol. 2008, 9, 575-580. [CrossRef]

29. Viuda-Martos, M.; Ruiz-Navajas, Y.; Fernández-López, J.; Pérez-Álvarez, J.A. Antifungal activities of thyme, clove and oregano essential oils. J. Food Saf. 2007, 27, 91-101. [CrossRef] 
30. Lattanzio, V.; Di Venere, D.; Linsalata, V.; Lima, G.; Ippolito, A.; Salerno, M. Antifungal activity of 2, 5-dimethoxybenzoic acid on postharvest pathogens of strawberry fruits. Postharvest Biol. Technol. 1996, 9, 325-334. [CrossRef]

31. Hussein, M.M.; Abo-Elyousr, K.A.; Hassan, M.A.; Hashem, M.; Hassan, E.A.; Alamri, S.A. Induction of defense mechanisms involved in disease resistance of onion blight disease caused by Botrytis allii. Egypt J. Biol Pest Control 2018, 28, 1-11. [CrossRef]

32. Avis, T.J. Antifungal compounds that target fungal membranes: Applications in plant disease control. Can. J. Plant Pathol. 2007, 29, 323-329. [CrossRef]

33. Liu, S.; Ruan, W.; Li, J.; Xu, H.; Wang, J.; Gao, Y.; Wang, J. Biological control of phytopathogenic fungi by fatty acids. Mycopathologia 2008, 166, 93-102. [CrossRef]

34. Spadaro, D.; Droby, S. Development of biocontrol products for postharvest diseases of fruit: The importance of elucidating the mechanisms of action of yeast antagonists. Trends Food Sci. Technol. 2016, 47, 39-49. [CrossRef]

35. Dukare, A.; Paul, S. Effect of chitinolytic biocontrol bacterial inoculation on soil microbiological activities and Fusarium population in rhizophere of Pigeon pea (Cajanus cajan). Ann. Plant Prot. Sci. 2018, 26, 98-103. [CrossRef]

36. Suman, A.; Yadav, A.N.; Verma, P. Endophytic microbes in crops: Diversity and beneficial impact for sustainable agriculture. In Microbial Inoculants in Sustainable Agricultural Productivity; Springer: New Delhi, India, 2016; pp. 117-143.

37. Gladieux, P. What makes a specialized endophyte special. Mol. Ecol. 2018, 27, 3037-3039. [CrossRef]

38. Hardoim, P.R.; Van Overbeek, L.S.; Berg, G.; Pirttilä, A.M.; Compant, S.; Campisano, A.; Döring, M.; Sessitsch, A. The hidden world within plants: Ecological and evolutionary considerations for defining functioning of microbial endophytes. Microbiol. Mol. Biol. Rev. 2015, 79, 293-320. [CrossRef]

39. Droby, S.; Wisniewski, M. The fruit microbiome: A new frontier for postharvest biocontrol and postharvest biology. Postharvest Biol. Technol. 2018, 140, 107-112. [CrossRef]

40. Zhang, H.; Xie, J.; Fu, Y.; Cheng, J.; Qu, Z.; Zhao, Z.; Cheng, S.; Chen, T.; Li, B.; Wang, Q.; et al. A 2-kb mycovirus converts a pathogenic fungus into a beneficial endophyte for brassica protection and yield enhancement. Mol. Plant 2020, 13, 1420-1433. [CrossRef]

41. Wu, T.; Xu, J.; Liu, J.; Guo, W.H.; Li, X.B.; Xia, J.B.; Xie, W.J.; Yao, Z.G.; Zhang, Y.M.; Wang, R.Q. Characterization and initial application of endophytic Bacillus safensis strain ZY16 for improving phytoremediation of oil-contaminated saline soils. Front. Microbiol. 2019, 10, 991. [CrossRef] [PubMed]

42. Branquinho, R.; Meirinhos-Soares, L.; Carriço, J.A.; Pintado, M.; Peixe, L.V. Phylogenetic and clonality analysis of Bacillus pumilus isolates uncovered a highly heterogeneous population of different closely related species and clones. FEMS Microbiol. Ecol. 2014, 90, 689-698. [CrossRef] [PubMed]

43. Hong, H.A.; Duc, L.H.; Cutting, S.M. The use of bacterial spore formers as probiotics. FEMS Microbiol. Rev. 2005, 29, 813-835. [CrossRef] [PubMed]

44. Pérez-García, A.; Romero, D.; De Vicente, A. Plant protection and growth stimulation by microorganisms: Biotechnological applications of Bacilli in agriculture. Curr. Opin. Biotechnol. 2011, 22, 187-193. [CrossRef]

45. Lateef, A.; Adelere, I.A.; Gueguim-Kana, E.B. The biology and potential biotechnological applications of Bacillus safensis. Biologia 2015, 70, 411-419. [CrossRef]

46. Ting, A.S.Y.; Chai, J.Y. Chitinase and $\beta$-1, 3-glucanase activities of Trichoderma harzianum in response towards pathogenic and non-pathogenic isolates: Early indications of compatibility in consortium. Biocatal. Agric. Biotechnol. 2015, 4, 109-113. [CrossRef]

47. Schönbichler, A.; Díaz-Moreno, S.M.; Srivastava, V.; McKee, L.S. Exploring the potential for fungal antagonism and cell wall attack by Bacillus subtilis natto. Front. Microbiol. 2020, 11, 521. [CrossRef] [PubMed]

48. Sipos, B.; Benkő, Z.; Dienes, D.; Réczey, K.; Viikari, L.; Siika-aho, M. Characterisation of specific activities and hydrolytic properties of cell-wall-degrading enzymes produced by Trichoderma reesei Rut C30 on different carbon sources. Appl. Biochem. Biotechnol. 2010, 161, 347-364. [CrossRef]

49. Parafati, L.; Vitale, A.; Restuccia, C.; Cirvilleri, G. Biocontrol ability and action mechanism of food-isolated yeast strains against Botrytis cinerea causing post-harvest bunch rot of table grape. Food Microbiol. 2015, 47, 85-92. [CrossRef]

50. Abdel-Rahim, I.R.; Abo-Elyousr, K.A. Talaromyces pinophilus strain AUN-1 as a novel mycoparasite of Botrytis cinerea, the pathogen of onion scape and umbel blights. Microbiol. Res. 2018, 212, 1-9. [CrossRef] [PubMed]

51. Xiao, Y.; Chen, S.; Gao, Y.; Hu, W.; Hu, M.; Zhong, G. Isolation of a novel beta-cypermethrin degrading strain Bacillus subtilis BSF01 and its biodegradation pathway. Appl. Microbial. Biotechnol. 2015, 99, 2849-2859. [CrossRef] [PubMed]

52. O'Brien, P.A. Biological control of plant diseases. Australas. Plant Pathol. 2017, 46, 293-304. [CrossRef]

53. Veliz, E.A.; Martínez-Hidalgo, P.; Hirsch, A.M. Chitinase-producing bacteria and their role in biocontrol. AIMS Microbiol. 2017, 3 , 689. [CrossRef]

54. Hura, G.L.; Budworth, H.; Dyer, K.N.; Rambo, R.P.; Hammel, M.; McMurray, C.T.; Tainer, J.A. Comprehensive macromolecular conformations mapped by quantitative SAXS analyses. Nat. Methods 2013, 10, 453-454. [CrossRef]

55. Benhamou, N.; Gagné, S.; Le Quéré, D.; Dehbi, L. Bacterial-mediated induced resistance in cucumber: Beneficial effect of the endophytic bacterium Serratia plymuthica on the protection against infection by Pythium ultimum. Phytopathology 2000, 90, 45-56. [CrossRef] [PubMed]

56. Anjum, N.A.; Ahmad, I.; Mohmood, I.; Pacheco, M.; Duarte, A.C.; Pereira, E.; Prasad, M.N.V. Modulation of glutathione and its related enzymes in plants' responses to toxic metals and metalloids-A review. Environ. Exp. Bot. 2012, 75, 307-324. [CrossRef] 
57. Osbourn, A.E. Preformed antimicrobial compounds and plant defense against fungal attack. Plant Cell 1996, 8, 1821. [CrossRef] [PubMed]

58. Lattanzio, V.; Lattanzio, V.M.; Cardinali, A. Role of phenolics in the resistance mechanisms of plants against fungal pathogens and insects. Phytochem. Adv. Res. 2006, 661, 23-67.

59. Khaledi, N.; Taheri, P.; Tarighi, S. Antifungal activity of various essential oils against Rhizoctonia solani and Macrophomina phaseolina as major bean pathogens. J. Appl. Microbiol. 2015, 118, 704-717. [CrossRef]

60. Baysal, D.; Balyk, R.; Otto, D.; Luciak-Corea, C.; Beaupre, L. Functional outcome and health-related quality of life after surgical repair of full-thickness rotator cuff tear using a mini-open technique. Am. J. Sports Med. 2005, 33, 1346-1355. [CrossRef] [PubMed]

61. Seleim, M.A.; Abo-Elyousr, K.A.M.; Mohamed, A.A.A.; Al-Marzoky, H.A. Peroxidase and polyphenoloxidase activities as biochemical markers for biocontrol efficacy in the control of tomato bacterial wilt. J. Plant Physiol. Pathol. 2014, 2, 2. [CrossRef]

62. Zhang, J.; Kirkham, M.B. Drought-stress-induced changes in activities of superoxide dismutase, catalase, and peroxidase in wheat species. Plant Cell Physiol. 1994, 35, 785-791. [CrossRef]

63. Abdel-Hafez, S.I.; Abo-Elyousr, K.A.; Abdel-Rahim, I.R. Leaf surface and endophytic fungi associated with onion leaves and their antagonistic activity against Alternaria porri. Czech Mycol. 2015, 67, 1-22. [CrossRef]

64. Domsch, K.H.; Gams, W.; Anderson, T.H. Compendium of Soil Fungi; Academic Press: London, UK, 1980.

65. Hashem, M.; Alamri, S. The biocontrol of postharvest disease (Botryodiplodia theobromae) of guava (Psidium guajava L.) by the application of yeast strains. Postharvest Biol. Technol. 2009, 53, 123-130.

66. Hassan, E.A.; Bagy, H.M.M.; Bashandy, S.R. Efficacy of potent antagonistic yeast Wickerhamiella versatilis against soft rot disease of potato caused by Pectobacterium carotovorum subsp. Carotovorum. Arch. Phytopathol. Plant Prot. 2019, 52, 1125-1148. [CrossRef]

67. Abo-Elyousr, K.A.M.; Asran, M.R. Antibacterial activity of certain plant extracts against bacterial wilt of tomato. Arch. Phytopathol. Plant Prot. 2009, 42, 573-578. [CrossRef]

68. Bauer, A.W. Antibiotic susceptibility testing by a standardized single disc method. Am. J. Clin. Pathol. 1966, 45, 149-158. [CrossRef]

69. Andrews, J.M. Determination of minimum inhibitory concentrations. J. Antimicrobial. Chemoth. 2001, 48, 5-16. [CrossRef]

70. Singh, J.; Tripathi, N.N. Inhibition of storage fungi of blackgram (Vigna mungo L.) by some essential oils. Flavour Fragr. J. 1999, 14, 1-4. [CrossRef]

71. Bouziane, Z.; Dehimat, L.; Aziz, W.A.; Benabdelkader, M.; Chaouche, N.K. The antagonism between Trichoderma viride and other pathogenic fungal strains in Zea mays. Agric. Biol. J. North AM 2011, 2, 584-590. [CrossRef]

72. Najjar, A.; Hassan, E.A.; Zabermawi, N.; Saber, S.H.; Bajrai, L.H.; Almuhayawi, M.S.; Abujamel, T.S.; Almasaudi, S.B.; Azhar, L.E.; Moulay, M.; et al. Optimizing the catalytic activities of methanol and thermotolerant Kocuria flava lipases for biodiesel production from cooking oil wastes. Sci. Rep. 2021, 11, 1-19.

73. Sanders, E.R. Aseptic laboratory techniques: Plating methods. J. Vis. Exp. 2012, 63, 3064. [CrossRef] [PubMed]

74. Brenner, D.J.; Krieg, N.R.; Staley, J.T.; Garrity, G.M. Bergey's Manual of Systematic Bacteriology; Volume 2 The Proteobacteria; East Lansing; Springer: New York, NY, USA, 2005; p. 183.

75. Lane, D.J. 16S/23S rRNA sequencing. In Nucleic Acid Techniques in Bacterial Systematics; Stackebrandt, E., Goodfellow, M., Eds.; John Wiley \& Sons: Chichester, UK, 1991; pp. 115-175.

76. Sanger, F.; Nicklen, S.; Coulson, A.R. DNA sequencing with chain-terminating inhibitors. Proc. Nat. Acad. Sci. USA 1977, 74, 5463-5467. [CrossRef]

77. Miller, G.L. Use of Dinitrosalicylic Acid Reagent for Determination of Reducing Sugar. Anal. Chem. 1959, 31, 426. [CrossRef]

78. Chen, J.P.; Lee, M.S. Simultaneous production and partition of chitinase during growth of Serratia marcescens in an aqueous two-phase system. Biotechnol. Tech. 1994, 8, 783-788. [CrossRef]

79. Palanivel, P.; Ashokkumar, L.; Balagurunathan, R. Production, purification and fibrinolytic characterization of alkaline protease from extremophilic soil fungi. Int. J. Pharm. BioSci. 2013, 4, 101-110.

80. Pereira, M.G.; Vici, A.C.; Facchini, F.D.A.; Tristão, A.P.; Cursino-Santos, J.R.; Sanches, P.R.; Jorge, J.A.; Polizeli, M.d.L.T.d.M. Screening of filamentous fungi for lipase production: Hypocrea pseudokoningii a new producer with a high biotechnological potential. Biocatal. Biotransform. 2014, 32, 74-83. [CrossRef]

81. Prazeres, J.N.d.; Cruz, J.A.B.; Pastore, G.M. Characterization of alkaline lipase from Fusarium oxysporum and the effect of different surfactants and detergents on the enzyme activity. Braz. J. Microbiol. 2006, 37, 505-509. [CrossRef]

82. Lowry, O.H.; Rosebrough, N.J.; Farr, A.L.; Randall, R.J. Protein measurement with the Folin phenol reagent. J. Biol. Chem. 1951, 193, 265-275. [CrossRef]

83. Bobev, S.G.; Zveibil, A.; Freeman, S. First Report of Colletotrichum acutatum on Strawberry in Bulgaria. Plant Dis. 2002, 86, 1178. [CrossRef] [PubMed]

84. Yaganza, E.S.; Rioux, D.; Simard, M.; Arul, J.; Tweddell, R.J. Ultrastructural alterations of Erwinia carotovora subsp. atroseptica caused by treatment with aluminum chloride and sodium metabisulfite. Appl. Environ. Microbiol. 2004, 70, 6800-6808.

85. Kofalvi, S.A.; Nassuth, A. Influence of wheat streak mosaic virus infection on phenylpropanoid metabolism and the accumulation of phenolics and lignin in wheat. Physiol. Mol. Plant Path. 1995, 47, 365-377. [CrossRef]

86. Sun, T.; Powers, J.R.; Tang, J. Evaluation of the antioxidant activity of asparagus, broccoli and their juices. Food Chem. 2007, 105, 101-106. [CrossRef] 
87. Misra, H.P.; Fridovich, I. The role of superoxide anion in the autoxidation of epinephrine and a simple assay for superoxide dismutase. J. Biol. Chem. 1972, 247, 3170-3175. [CrossRef]

88. Nakano, Y.; Asada, K. Hydrogen peroxide is scavenged by ascorbate-specific peroxidase in spinach chloroplasts. Plant Cell Phys. 1981, 22, 867-880.

89. Aebi, H. Catalase in vitro. Methods Enzymol. 1984, 105, 121-126. [PubMed]

90. Abo-Elyousr, K.A.; Ibrahim, Y.E.; Balabel, N.M. Induction of Disease Defensive Enzymes in Response to Treatment with acibenzolar-S-methyl (ASM) and Pseudomonas fluorescens Pf2 and Inoculation with Ralstonia solanacearum race 3, biovar 2 (phylotype II). J. Phytopath. 2012, 160, 382-389. [CrossRef]

91. Snedecor, G.; Cochran, W. Statistical Methods; Iowa State University: Ames, IA, USA, 1980. 